CENTRO DE HISTÓRIA DA SOCIEDADE

E DA CUlTURA DA UNIVERSIDADE DE COIMBRA

MANUEL AUGUSTO RODRIGUES

12

\title{
DO HUMANISMO À CONTRA-REFORMA \\ EM PORTUGAL
}

C O I M B R A

1981 
ObRas eM VIAS de pUBLICAÇão:

Fernando de Almeida Catroga, Positivismo e republicanismo no pensamento $e$ acção de Manuel Emidio Garcia

Maria Manuela Tavares Ribeiro, A. P. Lopes de Mendonça e os primórdios do socialismo em Portugal

Fernando de almeida Catroga, A filosofia social de Antero

Amadeu Carvalho Homem, A obra de Joaquim Antonio da Silva Cordeiro

ISABel Nobre Vargues, João Castelo Branco e o radicalismo vintista

Fernando de Almerda Catroga, A «questão política» em Antero de Quental

Manuel Augusto Rodrigues, D. Jerónimo Osório no âmbito do humanismo e da Contra-Reforma

Luís Manuel Reis Torgal, $O$ imperialismo na obra do Padre António Vieira 
DO HUMANISMO À CONTRA-REFORMA

EM PORTUGAL 


\author{
CENTRO DE HISTÓRIA DA SOCIEDADE \\ E DA CULTURA DA UNIVERSIDADE DE COIMBRA
}

MANUEL AUGUSTO RODRIGUES

\title{
DO HUMANISMO À CONTRA-REFORMA \\ EM PORTUGAL
}

C O I M B R A

1981 


\section{DO HUMANISMO À CONTRA-REFORMA EM PORTUGAL}

\section{HUMANISMO E HUMANISMO CRISTÃO}

O humanismo estava em franco desenvolvimento, havia mais de um século, em Itália, e afirmava-se já aquém dos Alpes, quando D. João III começou a reinar $(1521)(1)$.

(1) É bastante vasta a literatura consagrada a Erasmo. Aqui apenas referiremos alguma da mais recente. No domínio propriamente bibliográfico, poderá consultar-se: J.-C. MARGolin, Douze années de bibliographie érasmienne, 1950-1961, Paris, 1963; ID., Quatorze années de bibliographie érasmienne, 1936-1949; ibid., 1969; ID., Bibliographie érasmienne, 1962-1970, Paris-Toronto, 1977. - A edição de quase todas as obras de Erasmo geralmente consultada é a de J. Leclerc, Opera omnia D. Erasmi Roterodami, 10 ts. em 11 vols., in fol., Leiden, 1703-1706, que foi reproduzida em Hildesheim, 1962. - Encontra-se em curso de publicação a primeira edição crítica completa das obras de Erasmo que abrangerá mais de 50 vols. (Amsterdão, North Holland Publ. Comp. = ASD). Foi iniciada em 1969, tendo já sido publicados sete volumes. - Existem muitas edições parciais das obras do roterdamês, especialmente o Elogio da Loucura, os Colóquios e o Manual do cavaleiro cristão. - A correspondência de Erasmo editada por P. S. ALLen em 12 vols., Oxford, 1906-1958, está a ser traduzida para francês (Bruxelas-Paris, 1967 - 5 tomos dos 12 programados até 1976; e para inglês (Toronto, 1973 -, 3 tomos já aparecidos até 1976). - Entre os muitos estudos biográficos feitos nos últimos anos, podemos referir: J.-C. MARGolin, Erasme par lui-même, Paris, 1965 (reed. em 1970); P. MESNARD, Érasme ou le christianisme critique, ibid., 1969; L.-E.' HalkIN, Érasme et l'humanisme chrétien, ibid., 1969; R.-H. Bainton, Erasmus of christendom, Nova York, 1969; J. D. TRacy, Erasmus: The Growth of a mind, Genebra, 1972. - Entre os inúmeros trabalhos de indole histórica e crítica, merecem ser apontados: A. RENAUDET, Érasme, sa pensée religieuse et son action d'après sa correspondance, 1517-1521, Paris, 1926; ID., Études érasmiennes, 1521-1529, ibid., 1939; ID., Érasme et l'Italie, Genebra, 1954; ID., Humanisme et Renaissance, ibid., 1958; M. BATAILLON, Érasme et l'Espagne. Recherches surl'histoire spirituelle du XVIe. siècle, Paris, 1937 (reed. da versão esp. México, 1966); 
Trata-se de um fenómeno cultural complexo, em íntima conexão com o desenvolvimento das sociedades civis, de um e outro lado dos Alpes, e com a acumulação dos conhecimentos clássicos processada ao longo da Idade Média e acelerada na parte final desta.

Cobriu, ao mesmo tempo, o âmbito literário, o cultural e o religioso. Sem o recurso à sua mediação, mal se compreendem, na génese e na dialéctica, movimentos de tão aguda ressonância, como o evangelismo fabro-erasmiano, a marcha dos saberes e da axiologia para os centros de interesse laicos, a dissidência filosófica e científica antiescolástica.

Aparece, simultaneamente, como um corte de horizontes, um corte epistemológico e metodológico, e um corte de conteúdos com a cultura

M. MANN, Érasme et les débuts de la Réforme française, 1517-1536, ibid., 1934; Scrinium Erasmianum, 2 vols., Leiden, 1969-1970; Colloquia Erasmiana Turonensia, Paris-Toronto, 1972. - Sobre o pensamento religioso de Erasmo são de referir: J. ETIENNE, Spiritualisme érasmien et théologiens louvanistes, Lovaina, 1956; E.-W. KoHLs, Die Theologie des Erasmus, 2 vols., Basileia, 1966; C. BÉNÉ, Érasme et saint Augustin, Genebra, 1969; G. Chantraine, "Mystère» et «Philosophie du Christianisme selon Erasmes, Gembloux, 1971; J. B. PAYNE, Erasmus; his theology of the Sacraments, Richmond, 1970. - As ideias pedagógicas de Erasmo foram estudadas por J.-C. MARGolin, na edição comentada e acompanhada de tradução da obra De pueris instituendis (Genebra, 1966), entre outros. - Vid. ainda: O. SсHOTTENLOHER, «Erasme et la 'Respublica christiana'», in Colloquia Erasmiana Turonensia, t. II, pp. 667-690; E.-W. KoHLS, Luther oder Erasmus, Basileia, 1972; J. BorsseT, Erasme et Luther: Libre ou serf-arbitre?, Paris, 1962; M. Hoffmann, Erkenntnis und Verwirklichung der wahren Theologie nach Erasmus von Rotterdam, Tubinga, 1972; J.-C. Margolin, Guerre et paix dans la pensée d'Érasme de Rotterdam, Paris, 1973; J.-P. Massaut, "Humanisme et spiritualité chez Erasme», in Dictionnaire de spiritualité, ibid., 1969, cols. 1006-1028; M.-M. DE LA GANDERIE, Christianisme et lettres profanes, ibid., 1976; L. BOUyer, Autour d'Érasme. Études sur le christianisme des humanistes catholiques, ibid., 1955; E.-V. TelLE, Erasme de Rotterdam et le septième sacrement. Étude d'évangelisme matrimonial au XVIa siècle et contribution à la biographie intellectuelle d'Érasme, Genebra, 1954; ID., "Érasme et les mariages dynastiques», in Bibliothèque d'Humanisme et Renaissance, t. XII, pp. 7-13, Genebra, 1950; ID., "L'Ile des Alliances (Quart Livre, chap. IX) ou l'anti-Thélème», ibid., t. XIV, pp. 159-175, Genebra, 1952; A. RenaUdeT, Préréforme et humanisme à Paris pendant les premières guerres d'Italie (1497-1517), 2." ed., Paris, 1953; ID., Études érasmiennes (1521-1529), ibid., 1939; ID., Érasme et l'Italie, Genebra, 1954; ID., "Érasme et la prononciation des langues antiques», in Bibliothèque d'Humanisme et Renaissance, t. XVIII, pp. 190-196, Genebra, 1956; ID., «Érasme économiste», in Humanisme et Renaissance, pp. 194-200, Genebra, 1958; J.-B. PINEAU, Érasme, sa pensée religieuse, Paris, 1924; P. MESNARD, L'essor de la philosophie politique au XVIe siècle, 2. ${ }^{\mathrm{a}}$ ed., 
medieval. Um corte, isto é, uma viragem e não uma solução de continuidade. Muito do humanístico enraíza no medievo e não pouco do medievo sobrevive no humanístico. Mas o que dá o tom ao humanismo, o que faz dele um processo cultural diferente e o motivo de uma mudança qualitativa da cultura, com o seu auge de Galileu a Descartes, é o que em si é contra-medieval.

Através das belas letras, o humanismo tendia, de facto, para uma cultura que se mostrava laica por muitos dos seus conteúdos, e autónoma, por muitos dos seus princípios, em face da teologia.

A restitutio ou revocatio litteraria, por si praticada, significava a situação do clássico na história, ou seja, ideologicamente, em confronto com o medieval. Significava, por outras palavras, a instrumentalização

Paris, 1951; ID., "Les débuts de la pédagogie anglaise de la Renaissance», in Pédagogues et juristes, pp. 189-202, Paris, 1963; ID., «Le caractère d'Érasme», in Colloquium Erasmianum, pp. 327-332, Mons, 1968; ID., «La bataille du Ciceronianus», in Études, pp. 236-255, Paris, 1968; ID., Érasme ou le christianisme critique, ibid., 1969; O. GEBHARDT, Die Stellung des Erasmus von Rotterdam zur Römischen Kirche, Madburgo, 1966; E. Von Koerber, Die Staatstheorie des Erasmus von Rotterdam, Berlim, 1967. - A esta bibliografia deviam naturalmente acrescentar-se muitas outras obras. M. Batailion, F. Bierlaire, J. Coppens, R. Crahay, M. Cytowska, M. P. Gilmore, L.-E. Martin, J.-P. Massaut, M. A. Nauwelaerts, C. R. Thompson, G. Vallese, para só referir alguns, são autores que têm escrito muito sobre Erasmo e a sua obra.

Sobre o erasmismo em Espanha, vid. M. BATAILLON, Erasme et l'Espagne. Recherches sur l'histoire spirituelle du XVIt siècle, op. cit.; M. MENENDEZ Y Pelayo, Historia de los heterodoxos españoles, 2.a ed., 7 vols., Madrid, 1911-1932; D. Alonso, «El crepusculo de Erasmo», in Revista de Occidente, Madrid, t. XXXVIII, 1932, pp. 31-53; E. AsENsio, «El erasmismo y las corrientes espirituales afines», in Revista de Filología Española, t. XXXVI, 1952, pp. 31-99; M. BATLloRI, «Humanisme i erasmisme a Barcelona, 1524-1526», in Vuilt segles de cultura catalana a Europa, Barcelona, 1958, pp. 56-71; A. CASTRo, «Lo hispánico y el erasmismo», in Revista de Filologia Hispánica, Buenos Aires, t. II, 1940, pp. 1-34; t. IV, 1942, pp. 1-66; J. E. LoNGHuRST, «Alumbrados, erasmistas y luteranos en el proceso de Juan de Vergara», in Cuadernos de Historia de España, Buenos Aires, fasc. XXVII, 1958, pp. 99-163; fasc. XXVIII, 1958, pp. 102-121; fasc. XXIX-XXX, 1959, pp. 266-292; fasc. XXXI-XXXII, 1960, pp. 322-356; fasc. XXXV-XXXVI, 1962, pp. 337-353; fasc. XXXVII-XXXVIII, 1963, pp. 356-371; J. A. LlorenTe, Histoire critique de l'Inquisition d'Espagne, trad. de A. Pelliere, 2. ${ }^{a}$ ed., 4 vols., Paris, $1817-$ -1818 (reed. Madrid, 1980); M. Bataillon, Erasmo y el erasmismo, trad. do francês, Barcelona, 1977; J. CARO BaRoJA, Las formas complejas de la vida religiosa. Religión, sociedad y caracter en la Espana de los siglos XVI y XVII, Madrid, 1978; M. DE LA PINTA LloRente, Aspectos historicos del sentimiento religioso en España. Ortodoxia y heterodoxia, Madrid, 1961; A. DE VALdÉs, 
do clássico ao serviço da conquista de estruturas e metodologias, estéticas e culturais, superadoras do medievo. As litterae humaniores definem-se, neste contexto, como acessos à humanização, isto é, à desteologização da cultura e da análise do homem.

Despontou e afirmou-se o humanismo na Itália, nos séculos XIV e XV, antes de invadir as sociedades de aquém-Alpes nos fins do último século referido e no seguinte.

$\mathrm{O}$ aparecimento e avanço do humanismo está em correspondência com o avanço da sociedade civil. A cultura eclesiásticocêntrica respondia cada vez pior às necessidades e aos problemas desta sociedade em avanço. E porque a sociedade civil se desenvolveu primeiro e mais na Itália do que no mundo cisalpino, também o humanismo é não

Dialogo de las cosas ocurridas en Roma, ed. de J. F. Montesinos, Madrid, 1928, (versão inglesa com introd. e notas por J. E. LoNGHuRsx, Albuquerque, 1952); J. DE VAldes, Diálogo de doctrina cristiana (ed. facsim. de Alcalá de Henares de 1529 com introd. e notas por M. Bataillon, Coimbra, 1925). - Vid. os importantes trabalhos de E. Asensio, M. Morreale, J. I. Tellechea Idigoras, F. Rico, etc.

Sobre o humanismo francês, vid. A. RENAudet, Préréforme et humanisme à Paris pendant le premières guerres d'ltalie 1494-1517, op. cit.; L'humanisme français au début de la Renaissance, XIV Colloque international de Tours, Paris, 1973; M.-M. DE LA Garanderie, Christianisme et lettres profanes, ibid., 1976; F. Simone, La coscienza della Rinascita negli umanisti francesi, Roma, 1949.

Sobre o erasmismo na Europa do Norte, vid. F. SеEвон m, The Oxford Reformers, John Colet, Erasmus and Thomas More, Londres, 1867 (4.2 ed., 1911); P. S. AlLen, Erasmus: Lectures and Wayfaring sketches, Oxford, 1934; H. EXNER, Der Einfluss auf die englische Bildungsidee, Berlim, 1939; T. W. BaLDWIN, William Shakespeare's Small Latin and Less Greek, 2 vols., Urbana, Ill., 1944; M. MANN PHILlips, Erasmus and the Northern Renaissance, Londres, 1950 (Nova York, 1965); L. MILes, John Colet and the Platonic Tradition, Londres, 1962; G. MARC'HADOuR, L'Univers de Thomas More. Chronologie critique de More, Erasme et leur époque, 1477-1536, Paris, 1963; D. F. S. Thomson,-H. C. Porrer, Erasmus and Cambridge, Toronto, 1963; J. Mc ConICA, English Humanists and Reformation Politics under Henry VIII and Edward VI, Oxford, 1965.

Sobre o erasmismo nos Países Baixos, vid. o catálogo da exposição de Lovaina, «Erasmus en Leuven», Lovaina, 1969; o da exposição de Bruxelas, «Erasme et la Belgique, Bruxelas, 1969; o da exposição «L'humanisme et la littérature en Brabant», ibid., 1935; os das seguintes: «L'Europe humaniste», ibid., 1954-1955; e «CharlesQuint en son temps, ibid., 1955; W. Lourdaux, Moderne Devotie en Christelijk Humanisme..., Lovaina, 1967; A. Gerlo, «Erasme et les Pays-Bas», in Colloquia Erasmiana Turonensia.

Sobre o humanismo alemão, vid. L'humanisme allemand (1480-1540), XVIIIe Colloque International de Tours, Munique-Paris, 1979. 
só um fenómeno mais tardio, mas um fenómeno mais compósito, na França e na Alemanha Renana, nos Países Baixos e na Inglaterra, para já não falar de Espanha e de Portugal.

Não constitui, de maneira nenhuma, uma realidade linear o humanismo. Poderá dizer-se, sem exagero, que os humanismos não existiram menos do que o próprio humanismo. Os elementos diferenciais não têm menos importância do que os elementos comuns, nas várias concretizações históricas deste fenómeno cultural. Se a componente clássica se articula prevalentemente com a temática e a problemática profanas na Itália, articula-se mais com dominâncias religiosas na França e nos Países Baixos.

E se o humanismo cristão, com os seus denominadores antiescolásticos, antimedievos, antiformalístico-culturais, mas repassado de espiritualismo fabrista e erasmiano, pontifica deste lado dos Alpes, já o luterano, é na Itália do segundo quartel do séc. XVI que tem a principal sede.

O humanismo italiano tem uma identidade própria. E essa identidade consiste em ser, fundamentalmente, um humanismo literário, isto é, um interesse pelas letras humanas, uma cultura pelas letras humanas e referida aos problemas da vida terrena, sem dominâncias ou centralidades religiosas, colocada no polo oposto à metodologia escolástica e ao sacralismo medievo(2).

(2) Leo-Battista Alberti, Guarino de Verona, Vittorino da Feltre, Leonardo Bruni d'Arezzo, Pier Paolo Vergerio, Angelo Poliziano, Ermolao Barbaro, Enea Silvio Piccolomini, Giannozzo Manetti, Francesco Filelfo, Poggio Bracciolini, Bartolomeo Platina, Coluccio Salutati, Leo Batista Alberti, Giordano Bruno-eis alguns dos humanistas italianos mais ilustres. Sobre Pico della Mirandola, Marsilio Ficino, Lorenzo Valla, Maquiavel, fornecemos alguns dados bibliográficos atendendo à importância relevante que tiveram. O humanismo abrangeu vários domínios, desde o literário ao filosófico, do político ao das ciências. E daremos também una nota sobre Aldo Manucio.

Sobre Marsílio Ficino, vid. W. Dreıss, Die Mystik des Marsilius Ficinus, Berlim, 1929; J. FESTUGı̀̀re, La philosophie de l'amour de Marsile Ficin et son influence sur la littérature française du XVI $I^{e}$ siècle, Paris, 1941; P. O. KRISTELLER, The Philosophy of Marsilio Ficino, Nova Yorque, 1943; ID., Supplementum Ficinianum, 2 vols., Paris, 1957; ID., "Etat de la recherche sur Marsile Ficin», in Platon et Aristote à la Renaissance. XVI ${ }^{\mathrm{e}}$ Colloque International d'Études humanistes de Tours, ibid., 1976; R. MARCEL, Marsile Ficin, ibid., 1958; M. Ficino, Théologie platonicienne, com introd. e trad. de R. Marcel, 3 vols., ibid., 1964-1970; A. Chasrel, Marsile Ficin et l'art, ibid., 1954; S. R. JAYNE, Marsilius Ficinus, Columbia, 1944; Enciclopedia Cattolica, V, 1239 - 
Muito diferente é o panorama nos países cisalpinos. O anseio cultural e o anseio religioso são inseparáveis no humanismo cristão. E é por isso que este tanto se projecta à escala da teologia como à

-1243; M. Schiavone, Problemi filosofici in Marsilio Ficino, Milão, 1957; E. Gilson, «Marsile Ficino et le Contra Gentiles», in Archives d'histoire doctrinale et littérarie du Moyen Age, 24 (1958), pp. 101-113. - As obras mais relevantes de Marsílio Ficino são estas: Institutiones Platonicae, Firenze, 1456; Theologia Platonica, ibid., 1474; Opuscula, Veneza, 1498, etc.; Opera, Paris, 1641; P. O. Kristeller, Supplementun Ficianinum, 2 vols., Florença, 1937; R. MARCEL (ed), Commentaire sur le Banquet de Platon, Paris, 1956.

Sobre Maquiavel, vid. A Renaudet, Machiavel, 2.a ed., Paris, 1956; G. Mounin, Machiavel, nova ed., ibid., 1966 e 1969; L. Strauss, Thoughts on Machiavelli, Glencoe, Illianopolis, 1958; G. Sasso, Niccolo Machiavelli, storia del suo pensiero politico, Nápoles, 1958; J. R. MaLe, Machiavelli and Renaissance Italy, Nova Yorque, 1960; F. GILBERT, Machiavelli and Guicciardini, politics and history in XVIth century, Florença-Princeton, 1965; H. VÉdRINE, Machiavel ou la science du pouvoir, Paris, 1972; C. Lefort, Le travail de l'oeuvre, Machiavel, ibid., 1972; B. Gulllemain, L'homme de Machiavel, ibid., 1978; P. Villari, Nicolo Machiavelli ed i suoi tempi, Milão, 1877-1883; O. TOMasinI, La vita e gli scritti di Nicolo Macchiavelli nella loro relazione col macchiavellismo, Turim, 1882-1911 (reed. 1940-1942); R. Riddolfi, Vita di Nicolo Machiavelli, Roma, 1954 (trad. francesa, Paris, 1960); G. LAINI, Rinascimento Europeo, Bienne, 1965.

Sobre Pico de la Mirandola, vid. G. DI NAPOLI, Giovanni Pico della Mirandola e la problematica dottrinale del suo tempo. Florença, 1965; L'opera e il pensiero di Giovanni Pico della Mirandola nella storia dell'umanesimo. Convegno Internazionale (Mirandola: 15-18 Setembre 1963), Florença, 1965; G. Dr NAPOLI, Studi pichiani, Modena, 1975; H. de Lubac, Pic de la Mirandole, Paris, 1974; J.-C. Margolin, «Pic de La Mirandole», in Encyclopaedia Universalis, t. XIII, 27-30; H. VÉDRINE, «Microcosme et macrocosme», ibid., t. X, 1053-1055; J. V. DE PIna Martins, Pico della Mirandola e o Humanismo ilaliano nas origens do Humanismo português, Lisboa, 1964; ID., Fr. António de Beja, discipulo de Pico della Mirandola, ibid., 1965. - As suas obras mais importantes são as seguintes: De dignitate hominis, 1486; Apologia, 1487; Heptaplus, 1489; De ente et uno, 1491; Disputationes adversus astrologos, 1492-1494. Foram publicadas em conjunto em Bolonha, 1496; Basileia, 1572, e Florença, 1942-1951, em 3 vols., por E. Garin.

Sobre Aldo Manucio, o grande impressor do séc. XVI de Veneza, vid. M. DAzzI, Aldo Manucio e il Dialogo veneziano, Vicenza, 1963 (esta obra inclui a lista das edições aldinas): D. J. Geanakoplos, Greek scholars in Venice. Studies in the Dissemination of Greek Learning from Byzantinum 10 Western, Massachussets, 1962. - À volta dele formou-se uma verdadeira - Academia, da qual faziam parte Scipione Forteguerri, Marco Musuro, Niccolo Leonico Tomeo e Girolamo Aleandro. Erasmo, quando esteve em Veneza em 1508, recorreu várias vezes aos conhecimentos de grego do ilustre impressor veneziano. 
escala da espiritualidade. À escala da teologia, cientificando-a com a aplicação do método histórico-filológico (3), fazendo dela uma expla-

(3) Quanto ao conhecimento das línguas eruditas, Erasmo deixou-nos muitos dados que nos levam a concluir facilmente que esse era um domínio importante em que o humanismo cristão situava as suas exigências. Assim, em In Novum Tesramentum Praefationes (Methodus), diz a certa altura: "Iam quod ad eas attinet litteras, quorum adminiculo commodius ad haec pertingimus, prima cura debetur perdiscendis tribus linguis Latinae, Graecae, Hebraicae, quod constet omnem scripturam mysticam hisce proditam esse. Neque vero mihi protinus his resilias, amice lector, negotii difficultate ceu clava repulsus. Si non desit praeceptor, si non desit animus, minore paene negotio tres hae linguae discentur, quam hodie discitur unius semilinguae miseranda balbuties, nimirum ob praeceptorum inscitiam. Neque flagitamus, ut in his usque ad eloquentiae miraculum proveharis, satis est, si ad munditiam et elegantiam, hoc est mediocritatem aliquam progrediare, quod sufficiat ad iudicandum. Nam ut omnes ceteras humanas disciplinas negligamus, nulla ratione fieri potest, ut intelligas quod scriptum est, si sermonis, quo scriptum est, fueris ignarus». E prossegue: «Neque enim audienjos arbitror istos quosdam, qui cum in sophisticis tricis usque ad decrepitam aetatem computrescant, dicere solent: "Mihi satis est interpretatio Hieronymi". Sic enim potissimum respondent ii, qui ne Latine quidem scire curant, ut his etiam frustra verterit Hieronymus. Ceterum ut ne dicam interim plurimis modis referre, e suis haurias fontibus aliquid an e qualibuscunque lacunis. Quid, quod quaedam ob sermonum idiomata ne possunt quidem ita transfundi in linguam alienam, ut éandem lucem, nativam gratiam, parem obtineant emphasin? Quid, quod quaedam minutiora sunt, quam ut omnino reddi possint, id quod passim queritur clamitatque divus Hieronymus? Quid, quod permulta ab Hieronymo restituta temporum iniuria interciderunt, velut evangelia ad Graecam veritatem emendata? Quid, quod scriptorum vel errore vel temeritate tum olim vitiati sunt libri, tum hodie passim vitiantur? Postremo quid, quod nec ea, quibus Hieronymus haec restituit, satis intelliguntur, si linguas, quarum testimoniis nititur, prorsus ignores? Quod si semel sufficiebat Hieronymiana tı anslatio, quorsum tandem attinebat caveri pontificum decretis, ut veteris instrumenti veritas ab Hebraeorum voluminibus, novi fides a Graecorum fontibus peteretur? Certe iam tum verterat Hieronymus. Denique si haec satis erat, qui postea factum est, ut tot manifestariis ac pudendis erratis lapsi sint primi nominis theologi, id quod apertius est, quam ut vel negari possit vel dissimulari? In quibus est et ipse neotericorum omnium diligentissimus Thomas Aquinas, quem mihi parum propitium esse velim, si aut mentior aut contumeliae causa haec dico. Ne quid interim dicam de ceteris cum hoc haudquaquam conferendis mea quidem sententia». E dá exemplos de pessoas já avançadas em idade que se consagraram àqueles estudos: "Quod si Catonis exemplum leviter nos movet, ipse divus Augustinus iam episcopus, iam senex ad Graecas litteras puero degustatas quidem sed fastiditas reversus est. Rudolphus Agricola, unicum Germaniae nostrae lumen et ornamentum, annum egressus quadragesimum Hebraeas litteras discere nec erubuit, vir in re litteraria tantus, nec desperavit tam grandis natu. Nam Graecas adolescens imbiberat. Ipse iam undequinquagesimum agens 
nação da mensagem revelađa, um instrumento de edificação dos fiéis, e banindo do seu horizonte não só o método dialéctico, mas o intelectualismo escolástico. À escala da espiritualidade, porque pôs em evidência que é no espírito, no sentido cristão, na prática evangélica, na affectio ou vida interior, que reside a essência do cristianismo e do culto católico, e não nas observâncias externas, na piedade formalizada, no militantismo eclesiástico-político.

annum ad Hebraicas litteras olim utcunque degustatas cum licet recurro. Nihil est rerum, quod non efficiat humanus animus, modo sibi imperarit, modo impense velit. Et ad hoc ut dixi negotium qualiscunque mediocritas satis est, dum ea sane absit a temeritate, quae fere solet hoc audacius pronuntiare, quo minus exacte diiudicat. Felicior quidem hac in parte iuventus, at non desperandi senes». - Na Ratio seu compendium verae theologiae deparam-se-nos passos semelhantes. O roterdamês insiste na necessidade de conhecer os idiomas sacros sem o que não é possível penetrar nos segredos da palavra revelada: «Iam quod ad eas attinet litteras, quarum adminiculo commodius ad haec pertingimus, citra controversiam prima prima cura debetur perdiscendis tribus linguis, Latinae, Graecae et Hebraicae, quod constet omnem scripturam mysticam hisce proditam esse. Quarum cum Augustinus Latinam dumtaxat calleret, Graecam leviter attigisset, Hebraicam nec sciret nec speraret, tamen Iibro de doctrina Christiana secundo non dubitat harum cognitionem ad sacros codices vel intelligendos vel restituendos necessariam pronuntiare, quod quemadmodum incognitis elemehtorum figuris nemo legit quod scriptum est, ita sine cognitione linguarum nullus intelligit quod legit. Neque vero mihi protinus hic resilias, amice lector, negotii difficultate ceu clava repulsus. Si non desit animus, si non desit praeceptor idoneus, minore paene negotio hae tres linguae discentur, quam hodie discitur unius semilinguae miseranda balbuties, nimirum ob praeceptorum tum inscitiam tum inopiam. Atque hoc sane nomine par est, ut clarissimi viri Hieronymi Buslidii, quondam praepositi Ariensis, memoria sacrosancta sit cum omnibus honestarum disciplinarum studiosis tum praecipue theologiae candidatis, qui fraudatis etiam haeredibus ingentem pecuniarum vim in hunc usum legato reliquit, ut honesto salario pararentur, qui Lovanii tres linguas profiterentur. Cuius laudis non minima portio debetur et huius germano, Aegidio Buslidio, qui sic favet fratris testamento, immo sic litteris ipse litteratissimus, ut malit eam pecuniam iuvandis studiis omnium quam suis scriniis augendis dicatam. Exemplum hoc pulcherrimum gnaviter aemulatur vir omnium saeculorum memoria dignus, Stephanus Poncherius, quondam epiiscopus Parisiensis, nunc archiepiscopus Senonensis, undique praemiis amplissimis evocans, qui linguas doceant». Os dois nomes referidos são respectivamente De Busleiden (1470-1517), arquidiácono em Bruxelas e fundador do «Collegium Trilingue», no qual se ensinavam as línguas latina, grega e hebraica. Egídio de Busleiden viveu entre 1465 e 1536 . Estêvão Ponchter, presidente do Untersuchungsgerichtshofes de Paris, chanceler da Universidade e bispo de Paris, e desde 1519 bispo de Sens. E podíamos aduzir outros textos alusivos ao interesse que Erasmo dava à aprendizagem das linguas eruditas. 
Ninguém formulou de modo tão perfeito como Erasmo (4) a doutrina do humanismo cristão. A sua escola teve, porém, muitos e ilustres

(4) Acerca de Erasmo, são ainda plenas de actualidade as seguintes palavras de A. Renaudet: "L'oeuvre d'Erasme était moins diverse et moins profonde que celle de Lefèvre. Il n'avait pas exercé la lente, pénétrante et sûre action d'un professeur dont les livres, attendus et discutés, alternent avec les cours. Il avait longtemps hésité, cherché sa route. Après les tristes et besogneuses annés de ses sébuts, pendant lesquells, l'influence de Mombaer, un moment sembla le reconquérir à l'idéal mortifié des Windeshémiens il eut le bonheur de rencontrer à Oxford, John Colet, à Saint-Omer, Jean Vitrier. Il vit le réformateur anglais éprouver, à l'éxamen des textes bibliques, la méthode que les savants italiens appliquaient aux oeuvres des poètes, des orateurs et des philosophes; il connut son dédain des pratiques, sa piété simple et tout inspirée de l'Ecriture. Trois ansà après, Jean Vitrier lui enseignait un paulinisme hostile aux cérémonies, aux observances monacales. Ainsi Érasme découvrit sa discipline intellectuelle et morale, le but de son action scientifique et religieuse. Dès 1500, dans la préface des premiers Adages, il avait souhaité la réconciliationi de la culture gréco-latine et de la croyance chrétienne; en 1504, il définit, dans l'Enchiridion, la théologie nouvelle, expose son propose idéal, son christianisme libéré des cérémonies et des formules. La science de l'antiquité classique et l'expérience de la vie humaine que révèlent les Adages de Venise, le talent et la virtuosité qui éclatent à chaque page de l'Élogie de la Folie, aident à propager sa doctrine et son système. Et $\mathrm{u}$, dès l'apparition de l'Enchiridion, on retient dans la bourgeoise parlementaire, sa critique de la vie claustrale, dès 1505 les humanistes ont lu son édition des Notes de Laurent Valla sur le Nouveau Testament; ils savent à quelles études et à quelles recherches Érasme convie les théologiens». E de Lefèvre escreve: «Lefèvre, avant lui, s'y esaye; il édite, avant lui, les textes bibliques; en 1509 le Psautier, en 1512 les Épitres de saint Paul. Comme le veut Érasme, il examine la lettre en philologie, ne craint pas de contredire les doctuers, de rejeter au nom de la grammaire la tradition qui attribue la Vulgate à saint Jérôme. Il pratique une exégèse très libre, écarte les commentateurs modernes, n'admet d'autre source du dogme que l'Écriture. Pourtant son esprit enclin à voir partout des symboles et des images justifie sans peine croyances et institutions; malgré la hardiesse théorique de sa méthode, malgré son interprétation personelle de la doctrine des sacrements, malgré son abandon mystique à la grâce divine, il admet les oeuvres, le culte des saints et la Vierge, la présence réelle. Bien que, dans le commentaire des Epîtres, il déplore les abus de la cour pontificale, la violence et l'ambition de Jules II, le zèle insuffisant des prélats, peut-être blâme-t-il Érasme d'avoir, dans un livre de ton léger destiné à d'autres que des théologiens, dévoilé dans charité les plaies de l'Église. Longtemps des différences d'idéal, de caractère, de tempérament, ont séparé les deux écrivains. Érasme ne partage pas le mysticisme de Lefèvre, son goût pour les spéculations obscures de Lulle et de Cusa, son ascétisme monastique. Lefèvre n'approuve pas Érasme d'aimer si vivement la civilisation corrompue des gentils, et de cultiver auprès de leurs sceptiques, une tendance peu chrétienne à l'ironie. Mais, en 1514 , le procès de Reuchlin, la condamnation de ses livres par les scolas- 
mestres, de várias nacionalidades e em várias partes da Europa. Basta recordar o que se passou em Espanha, em França e nos Países Baixos, respectivamente em Salamanca e Alcalá, em Paris e Bordéus, e em Lovaina.

No primeiro daqueles países, ou seja, em Espanha, sobressairam Nebrija (5), Aires Barbosa (6), Hernan Nuñez(7) e Luís

tiques, rapprochent et unissent, pour défendre la cause menacée de la culture humaine, l'éditeur des Épîtres et l'auteur de l'Éloge; deux ans après, le succès du Nouveau Testament de Bâle consacre le triomphe de la théologie moderne et la gloire européenne d'Érasme. Si le texte, médiocrement établi, accuse un travail précipité, si le commentaire manifeste un sens religieux que déjà Luther juge médiocre, quelques pages durables de la préface, de la Paraclesis, de la Methodıs, fixent en termes décisifs, pour les générations qui vont venir, les règles sur lesquelles se fonde, avec l'exégèse restaurée, la critique moderne de l'Ecriturè (A. RENAUDET, Prèréforme et Humanisme à Paris pendant les premières guerres d'Iralie (1494-1517), 2.a. ed., Paris, 1953, pp. 700-701).

(5) Vid. sobre Elio Antonio de Nebrija: Nicolau Anronio, Bibliotheca Hispana Nova, I (1783), pp. 132-139; P. Fellx G. Olmedo, Humanistas y pedagogos españoles: Nebrija (1441-1522), debelador de la barbarie, comentador eclesiástico, pedagogo y poeta, Madrid, 1942; C. LóPEZ MARTínez, Elio Antonio de Nebrija, maestro $y$ publicista, Sevilha, 1947; R. B. TATE, «Nebrija the Historian», in Bulletin of Hispanic Stıdies, XXXIV, 1957, pp. 125-146; J. LuIs ALBorg, Historia de la literatura españala, 2. ${ }^{a}$ ed., Madrid, 1975, pp. 519-531 (com abundante bibliografia). - As obras de Nebrija mais notáveis são: Apologia, cum quibusdam sacrae Scripturae locis non vulgariter exposotis, s.l., n.a.; Apologia earum rerum quae illi objiciuntur... Ejusdem... Tertia quinquagena..., Granada, 1535; De litteris hebraicis, cum quibusdam annotationibus in Scripturam sacram, Alcalá (ca. 1515); Libri Minores..., Alcalá, 1526; Repetitio tertia, de peregrinarum dictionum accentu, s.l., 1506; Tertia quinquagena, Alcalá, 1516.

$\left.{ }^{6}\right)$ Sobre Aires Barbosa, vid. A. DA RochA BRito, «O aveirense Aires Barbosa, o italiano Pedro Mártir e a sífilis», in Arquivo do Distrito de Aveiro, n. ${ }^{\circ} 48$, pp. 281-296; Aveiro, 1946; F. Ferreira Neves, «Vida e testamento do humanista Aires Barbosa», ibid., XIV, 1948, pp. 281-296; J. Pérez RiesCo, Aires Barbosa, el «Maestro Griego», Madrid, 1948 (dactil.); W. DE SousA Medelros, Aires Barbosa. Esboço biobliográfico, seguido do texto e versão da «Antimoria», Lisboa, 1953 (dactil.); A. DE Jesus MARQUeS, Portugal e a Universidade de Salamanca. Participação dos escolares lisos no governo do Estudo; 1503-1512, Salamanca, 1980. - As obras mais importantes de Aires Barbosa são as seguintes: In uerba M. Fabii: Quid? quod \& reliqua. Relectio de uerbis obliquis, Salamanca, 1511; Aratoris Cardinalis Historia Apostolica cum commentariis..., ibid., 1516; Relectio cui titults... Prosodia et Orthographia, ibid., 1517; Antimoria, Coimbra, 1536, (há uma versão de J. P. TAVAres e A. G. DA Rocha Maball, Aveiro, 1960); Eiusdem nonnulli Epigrammata, Coimbra, 1536. Poesias e cartas estão impressas em obras de contemporâneos.

$\left.{ }^{7}\right)$ Sobre Hernán Nunez, vid. Marcel Bataillon, Erasmo y España, op. cit. - Daquele autor indicamos as seguintes obras: La Historia de Bohemia en roman 
Vives $\left(^{8}\right)$, que procuraram ligar a cultura literária com a cultura teológica, transpor a metódica específica da cultura profana para o sector uma forte oposição à escolástica, ao congreganismo, ao formalismo

(traduzida de Eneas Silvio), Sevilha, 1509; Observationes Fredenandi Pintiani in loca obscura aut depravata Historiae naturalis C. Plinii, Salamanca, 1544; Refranes o proverbios en romance que nuevamente colligió y gossó el Comentador Hernán Núnez, ibid., 1555.

(8) Juan Luis Vives, grande pedagogo, nomeadamente professor das línguas clássicas, e escritor de raro talento, leccionou também latim em Lovaina (1521). Manteve estreitas relações com humanistas famosos, como Erasmo, Budé, Morus e F. v. Cranefeld. A pedido de Erasmo editou uma edição crítica da obra de S. Agostinho, De civitate Dei (Basileia, 1522) com um comentário, que dedicou a Henrique VIII da Inglaterra. Por isso e porque defendeu Tomas Morus, veio a ser convidado para reger uma cadeira de línguas clássicas e jurisprudência no colégio «Corpus Christi» de Oxford. Depois viria a deixar esse lugar após o cisma de Inglaterra. Acerca de Vives, escreve K. Deuringer: "Als Gelehrter und Publizist umfasste Vives mit einem breiten und gründlichen Wissen die gesamete Problematik seiner Zeit; er trug sie vor in bestem, an den Klassikern geschultem Latein. Seine Zeitkritik drängte im Bereich der Kirche auf religiöse und sittliche Erneuerung; trotz aller Kritik blieb er der Kirche ohne jedes Schwanken innerlich und äusserlich treu, obwohl Vives einer neubekehrten judenchristlichen Familie entstammte, aus welcher beide Eltern und zahlreiche weitere Angehörige wegen Rückfalls ins Judentum Opfer der Inquisition wurden. Im politischen Bereich war seine grosse Sorge der Friede und die Einigkeit unter den christlichen Staaten gegenüber deın vordrängenden Islam; im sozialen Bereich drängte er auf die Herbeifuhrung der «Concordia» durch freiwilligen Ausgleich in Liebe. Seine dauerhafteste Fernwirkung liegt im Bereich der Erziehung der Jugend und der Erwachsenbildung». E prossegue o mesmo autor, referindo-se à sua personalidade: "Als Persönlichkeit war Vives harmonisch ausgelichen; von einem deutlichen Weltschmerz geprägt, neigte er zu negativer Neurteilung seiner Zeit; sein Pessimismus wurde jedoch ausgeglichen durch eine tiefe personale Religiosität, die in ihrem Äusserungen an die Devotio moderna (Imitatio Christi) erinnert. Vives war kontaktfahig und freundschaftsbedürftig; seine Ehe mit Margaretha Valdaura (1524) bedeutete ihm ein lebenslanges Glück. Für den äusseren Erfolg fehlten ihm Ehrgeiz und Robustheit; er blieb sein Leben lang arm und von wirtschaftlocher Not bedrängt («tenuis et bonarum omnium rerum egenus»). Bezüglich des Quellgrundes für sein Schaffen vergleiche die folgende Briefnotiz: «Neque enim ad ostentationem ingenii et vanitatem quandum philosophamur, sed ut vitam nostram praeceptis sapientiae accomodemus». - Sobre Vives, conf. Literae virorum eruditorum ad Franciscum Craneveldium 1522-28, ed. por H. DE Vocht, Lovaina, 1928; ID., "Vives and his visits to England», in Monumenta Humanistica Lovaniensia (Humanistica Lovaniensia, IV), ibid., 1934, 1-60; A. Bonllla y SAN MARTín, Luis Vives y la filosofia del Renascimiento, 3 vols., Madrid, 1929 (reed. 1981); M. BAtaillon, Erasmo y España, op. cit.; A. M. SAlAZAR, «Iconografia de Juan Luis Vives durante los siglos XVI, XVII y XVIII», in Boletin de la Real Academia de la Historia, 133 (Madrid 1953), 304-441; J. DE PAlacio y PALAClo, Proceso de Inquisición contra la 
filosófico-teológico e apresentar religioso e à inteligência teológica medievalista, sob a influência não só de Erasmo como também de Juan e de Alfonso de Valdés (9).

familia judia de Juan Luis Vives, I: Processo contra B. March, madre del Humanista, Madrid, 1964; J. B. Gomís, Criterio social de Luis Vives, Madrid, 1946. F. DE URMENETA, La doctrina psicológica y pedagógica de Luis Vives, Barcelona, 1949; M. BATAILLON, «Juan Luis Vives, reformateur de la bienfaisance», in Bibliothèque d'Humanisme et Renaissance (Mélanges A. Renaudet), 14 (1952, 141-158; J. CorTS GraU, «La doctrina social de Juan Luis Vives», in Estudios de Historia Social de España, II, Madrid, 1952; 63-89; B. MonSEGứ, «La doctrina cristológica de Juan Luis Vives», in Estudios Franciscanos, 55 (Barcelona 1954), 429-458; J. Kraus, Menschenbild und Menschenbildung bei Juan Luis Vives, Munique. 1956 (dissertação dactilografada); M. Sancipriano, Il pensiero psicologico e morale de Giovanni Ludovico Vives, Florença, 1957; J. M. CASTÁN VÁsquez, "La enseñanza del Derecho según Luis Vives», in Homenaje a N. Pérez Serrano, I, Madrid, 1959, 62-81; C. VAsoli, Juan Luis Vives e un programına umanistico di riforma della logica, Florença, 1961; B. G. MonseGú, Filosofia del humanismo en Juan Luis Vives, Madrid, 1961; K. DeURINGER, in Lexikon für Theologie und Kirche, X, 829-830. - Vives escreveu obras de índole teológica, filológica, sócio-pedagógica, filosófica, pedagógica, sócio-crítica e política, que aqui não enumeramos para não alongar esta nota. Os Opera omnia, em 2 vols., Basileia, 1555, e em 8 vols., Valência, 1782-88 (ed. por G. Mayáns) abrangem cerca de 59 livros; há ainda a registar 110 cartas que não figuram nos Opera omnia, muitas das quais já foram publicadas. Uma versão espanhola de toda a obra de Vives, incluindo as cartas, foi feita por L. RIBer, 2 vols., Madrid, 1947. Sobre outras edições, traduções e monografias, vid. Bibliographia philosophica 1934-45, ed. por A. DE Brie, Utrecht, 1955, n. ${ }^{\circ 5}$ 10292-10342; F. MATEU Llopis, Catálogo de exposición bibliográfica... Luis Vives, Barcelona, 1940; J. EsTEBRICH, Vives, Exposition organisée à la Bibliothèque Nationale de Paris 1941, Dijon, 1942.

(9) Sobre Alfonso e Juan Valdés, vid. Marcel Batalllon, Erasmo y España, op. cit.; J. LuIS AlborG, Historia de la literatura española, 2. ${ }^{a}$ ed., Madrid, 1975 (com bibliografia), pp. 706-722; E. BoHMER, Livres of the Twin Brothers Juan and Alfonso de Valdés, Londres, 1888; M. Menéndez Pelayo, Historia de los Heterodoxos españoles, III, Santander, 1946; G. BaGnatori, «Cartas inéditas de Alfonso Valdés sobre o Reichstag de Augusburgo", in Bulletin Hispanique, 57 (Bordéus 1955), 353-374; Domingo de Santa Teresa, Juan de Valdés 1498 (?) a 1541. Su pensamiento religioso y las corrientes espirituales de su tiempo, Roma, 1957 (com abundante bibliografia); J. I. Tellechea Idigoras, «Juan Valdés y Carranza", in Revista de Estudios Teológicos, 21 (1961), 289-324; J. N. BaKhuizen VAN DEN BRINK, Juan Valdés, Augsburgo, 1962; E. CIONE, Juan de Valdés. La sua vita e il suo pensiero religioso, $2 .^{\mathrm{a}} \mathrm{ed}$., Nápoles, 1963. - Principais obras: De Alfonso Valdés; Diálogo de las cosas ocurridas en Roma, 1529; Diálogo de Mercurio y Carin, 1529. De Juan Valdés: Diálogo de la doctrina cristiana, Alcalá, 1529 (nova ed. de Marcel Bataillon, Coimbra, 1925); Diálogo de la lengua, ed. por J. F. MonTESInos, Madrid, 1928; Alfabeto cristiano, ed. por B. CROCE, Bari, 1928; Le cento e dieci divine considerazioni, ed. por E. BOHMER, Heidelberg, 1860; Istruzione cristiana, Roma-Florença, 1884. 
Em França, por volta de 1525-1530, já os humanistas ocupavam quase todas as cátedras das Faculdades de Artes, não obstante a resistência oferecida por muitos mestres teólogos e escrituristas. O Organon de Aristóteles era substituído pelas obras de Rudolfo Agrícola (10) e de Lourenço Valla (11); davam-se passos gigantescos no sentido de superar a mentalidade escolástica ; correlacionava-se o humanismo com a problemática religiosa da época e dava-se à teologia, à pastoral e à exegese bíblica um lugar proeminente. Com Bovelles, Beatus Renanus, Jerónimo Aleandro, Postel, Vatablo e, sobretudo, com o Colégio de Santa Bárbara, processou-se, em França, uma autêntica revolução cultural.

Nos Países Baixos, as novas ideias humanísticas impuseram-se graças, em especial, a Rudolfo Agrícola, Gaguin (12), Clichtove (13),

(10) Sobre Agrícola, vid. J. V. D. VeLden, Rudolf Agricola, Leiden, 1911; A. FAust, "Die Dialetik Rudolfs Agricolas», in Archiv für Geschichte der Philosophie, 34 (1922), 118-135. - As suas obras principais são: De inventione dialectica (1479); De formando studio (1484), ambas editadas em Colónia em 1539; In laudem Philosophiae... oratio (1476), publicada na Deutsche Literatur in Entwicklungsreihen, Reihe Humanismus und Renaissance, II, ed. por H. Rupprich, Leiden, 1935, pp. 164-183.

(11) Sobre Lorenzo Valla, vid. F. GAETA, Lorenzo Valla. Filologia e storia nell'umanesimo italiano, Nápoles, 1955; G. DI NAPOLI, Lorenzo Valla. Filosofia e religione nell'umanesimo italiano, Roma, 1971; S. I. CAMpOREALE, Lorenzo Valla. Umanesimo e Teologia, Florença, 1972; L. Valla, Collatio Novi Testamenti, ed, por A. Perosa, Florença, 1970. - As obras de Valla, In latinam Novi Testamenti interpretationem adnotationes, ed. de Erasmo, Basileia, 1541; Elegantiarum libri sex, diversis prototypis collatis, grangearam-lhe grande reputação.

(12) Sobre Gaguin, vid. F. SImONE, «Robert Gaguin e il suo cenacolo umanistico"), in Aevum, Julho-Setembro de 1939, 410-476. - Gaguin escreveu De origine et gestis Francorum compendium (1495). Acerca do prestígio deste célebre humanista, escreve J.-C. Margolin: «Le prestige de Gaguin, associé à celui de l'Université de Paris, est tel que le jeune Erasme, encore inconnu Iors de son premier séjour sur les pentes de Ia Montagne-Sainte-Geneviève, attitera d'attention sur lui par la publication, à la suite du Compendium - ce sera le premier texte imprimé du Hollandais -, d'une lettre d'hommages à Gaguin, historien de la France. Quant à Paris, c'est en ces termes que l'exalte l'humaniste italien, Filippo Beroaldo qui était venu y faire un séjour professoral en 1476: «Paris est l'illustre patrie de tous les arts...: ici la philosophie a grandi, mère de toutes les disciplines, directrice de la vie humaine, maîtresse de l'art de vivre; ... ici se tiennent ses assises sacrées. J'ai donc pensé faire oeuvre méritoire, si j'enseignais ici les humanités et la poésie, si je montrais comme elles s'accordent et s'apparentent avec la philosophie...) (J.-C. MARGoLIN, L'avènement des temps modernes, op. cit., p. 230).

(13) Sobre Clichtove, vid. J.-P. Massaut, Josse Clichtove: l'humanisme et la réforme du clergé, 2 vols., Paris, 1968 (com abundante bibliografia); E.-V. TELLE, 
João Campense, Cochlaeus (14), Rescius e ao Colégio Trilingue de Lovaina, que se revelou como o principal instrumento de luta contra os esquemas culturais medievais e escolásticos e de defesa da união do cristianismo com o humanismo, segundo as esperanças manifestadas por Erasmo em carta dirigida a Capito.

Não pode falar-se do humanismo, sobretudo do humanismo cristão, sem se falar ao mesmo tempo da crise religiosa da cristandade que a Idade Média modelara. Essa crise avista-se já, nos fins do séc. XIV, com o cisma do papado, a feudalização do alto clero, a decadência dos institutos religiosos, principalmente dos monásticos, e a formalização da prática religiosa dos fiéis.

Erasme de Rotterdam et le septième sacrement, Genebra, 1954; 1D., Dilutio eorum quae Jodocus Clichtoveus scripsit adversus Declamationem Desiderii Erasmi suasoriam Matrimonii d'Erasme, Paris, 1968 (ed. crítica comentada); J. A. Clerval, De Judoci Clichtovei Neoportuensis doctoris Parisiensis et Carnotensis vita et operibus, Paris, 1894; ID., art. in Dictionnaire de Théologie Catholique, vol. IIl, 236-243; A. RenAUDET, Preréforme et humanisme à Paris pendant les premières guerres d'Italie (1494-1517), op, cit.; art. in Catholicisme, vol. II, 1248 ss. - Algumas obras de Clichtove: Theologia vivificans Dinoysii Areopagitae, interprete Ambrosio camaldulensi, cum scholiis Fabri et commentariis Clichtovei, Paris, 1514; D. Bernardi opera, ibid., 1515; Antilutherus, ibid., 1524; De sacramento eucharistiae conira Oecolampadium, ibid., 1526; Compendium veritatum ad fidem pertinentium, contra erroneas Lutheranorum assertiones, ibid., 1529; De laude monasticae religionis opusculum, ibid., 1513; De vita et moribus sacerdotum, ibid., 1519; De doctrina moriendi, ibid., 1521.

(14) Sobre Cochlaeus, vid. A. HERTE, Die Lutherkommentare des Johannes Cochlaeus (Dobeneck), Münster, 1935; W. Friedensburg, "Johannes Cochlaeus im Schmalkaldischen Kriege», in Zeitschrift für bayerische Kirchengeschichte, 10 (1935), pp. 151-156; A. Herte-K. A. MeIssinger, in Theologie und Glaube, 36 (1944), pp. 53-63; J. LorTz, Die Reformation in Deutschland, 2 vols., 3. a ed., Friburgo i.B., 1949; I, p. 208 s.; 261 ss.; II, 154-160; K. LANGOSCH, Zur Germania des Johannes Cochlaeus: Liber Floridus, Mittellateinische Studien Paul Lehmann z. 65. Geburtstag, St. Ottilien, 1950, pp. 373-384; H. JEDIN, Geschichte des Konzils von Trient, passim; E. ISERLOH, Der Kampf um die Messe in den ersten Jahrzehnten der Austinandersetzung mit Luther, Münster, 1951; R. KASTNER, «Cochlaeus und das Priestertum», in Archiv für schlesische Kirchengeschichte, 10 (1952), 84-105; F. W. Kantzenbach, Das Ringen um die Einheit der Kirche, Estocarda, 1957, pp. 143-150; vid. mais bibliografia in SCHOTrenLOHER, Bibliographie..., 2986-3033. - A sua obra mais notável são os Comentaria de actis et scriptis Martini Llitheri, Mainz, 1549, a primeira grande biografia de Lutero e a fonte contemporânea mais importante para a história da Reforma. As suas críticas bastante duras contra Lutero marcaram a figura do reformador na perspectiva católica durante muitos séculos. Cochlaeus escreveu mais de duzentos trabalhos. 
Acentuou-se, porém, durante o séc. XV e a primeira metade do séc. XVI. A Igreja hierárquica, a despeito dos protestos e apelos que subiam de vários países e quadrantes, a despeito do que se disse e votou nos concílios de Constança e $V$ de Latrão, não assumiu a crise nem dinamizou as lutas para a superar.

É manifesto, e cada vez mais manifesto, do limiar do séc. XV ao primeiro quartel do séc. XVI, o anseio de acrisolamento moral do clero e de repurificação da prática cultual dos fiéis. Inserem-se dentro deste contexto os esforços de vários padres conciliares, dos novos institutos religiosos, com especial destaque para os Irmãos da Vida Comum, e das observâncias mendicantes. Estes esforços processaram-se, todavia, no contexto das perenidades eclesiais e culturais legadas pela Idade Média. Procuravam moralizar as pessoas e acendrar o culto sem tocar nas estruturas existentes.

Esta linha tornou-se insustentável depois das revoltas luterana, zwingliana e calvinista. Os intelectuais, os políticos e os militantes católicos dividiram-se perante esta gravíssima ruptura verificada no corpo da Igreja.

Uns, os integristas, consideraram chegado o momento de uma rigidez doutrinária, de uma cristalização do legado medievo, como estimulante e pressuposto de uma luta - a luta pela unidade da Igreja, isto é, pela aniquilação das dissidências religiosas - a qual, no seu critério, teria de passar por grandes polémicas ideológicas e grandes repressões políticas.

Outros, "grosso modo» os evangelistas e os irenistas cristãos, julgaram que tinha soado a hora dos «aggiornamentos» da doutrina e da praxe, e que os simples «aggiornamentos» superariam a crise e as suas sequelas.

Entre estes e aqueles, mais distantes daqueles do que destes, surgiram os reformistas - os que esperavam de reformas eclesiais, espirituais, morais e culturais, senão o restabelecimento da unidade da Igreja, a minimização do fenómeno protestante. A última é a barreira da reforma católica.

A reforma católica recusava no evangelismo os enunciados que o aproximavam do protestantismo. Recusava, pois, o anticurialismo, o antimonaquismo, o antiescolasticismo, a universalização do sacerdócio, a negativa oposta às constituições apostólicas, à veneração das imagens e relíquias, à mediação dos santos, à piedade cerimoniática, etc. 
Em contrapartida, aceitava, embora reformulando-os, os princípios da espiritualização do culto, da promoção da oração interior, da purificação do sacerdócio, da restauração moral do congreganismo, da evangelicidade e austeridade dos costumes cristãos, do diálogo com os dissidentes, da tolerância religiosa.

A reforma católica foi um momento transitório na confrontação da Igreja católica com a sua crise interna e com o surto do protestantismo. O concílio de Trento converteu-a num simples factor da Contra-Reforma - num factor que o inquisitorialismo, a permanência do formalismo cultual, a aliança dos meios e poderes eclesiásticos com os meios e poderes seculares, a intolerância religiosa, a valorização do aparelho burocrático da Igreja, empobreceram drasticamente.

É dentro deste contexto que podemos falar da superação do evangelismo e do irenismo e do fracasso do humanismo cristão.

Havia diferenças consideráveis de ponto de vista, na concepção do cristianismo e da vida cristã, entre o evangelismo fabrista e o humanismo erasmiano. Erasmo transformou o espiritualismo místico de Lefèvre (15) numa espécie de idealismo personalista, rompeu quase por

(15) Sobre Lefèvre d'Étaples, vid. A. RENAUdET, Preréforme et humanisme a Paris pendant les premières guerres d'ltalie 1494-1517, op. cit.; E. F. RICE, Jr., The prefatory Epistles of Jacques Lefèvre d'Étaples and related Texts, Nova Yorque e Londres, 1972; G. BEDOUELLE, Lefèvre d'Étaples et l'intelligence des Écritures, Genebra, 1976; E. Amman, "Lefèvres d'Étaples (Jacques)», in Dictionnaire de Théologie Catholique, vol. IX/1, 132-159; L. FèBvre, Au coeur religieux du XVI siècle, Paris, 1957; ID., Le probleme de l'incroyance all XVIe siècle. La religion de Rabelais 2. 'ad., ibid., 1968; С ${ }^{2} .-\mathrm{H}$. GRAF, Essai sur la vie et les écrits de Jacques Lefèyre d'Étaples, Estrasburgo, 1842 (reed. Genebra, 1970); F. HAHN, «Faber Stapulensis und Luther", ìn Zeitschrift für Kirchengeschichte, 57 (1938), 356-432; H. HELLER, «The Evangelicism of Lefèvre d'Etaples: 1525», in Studies in the Renaissance, 19 (1972), 42-77; J. B. PAYNE, "Erasmus and Lefèvre as Interpreters of Paul», in Archiv für Reformationsgeschichte, 65 (1974) 54-83; E. F. RiCE, Jr., «Jacques Lefèvre d'Étaples and the Medieval Christian Mystics», in Florilegium historiale, Toronto, 1971; M. A. SREECH, J. Lefèvre d'Etaples et ses disciples, Epistres $€ t$ Evangiles pour les cinquante et deux semmaines de l'an, Genebra, 1964; ID., Le Nouveau Testament, 2 vols., Paris-La Haye, 1970; F. SeCret, «Les Dominicains et la Kabbale chrétienne», in Archivum Fratrum Praedicatorum, XXVII (1957), 319-336; ID., Les Kabbalistes chrétiens de la Renaissance, Paris, 1964; G. Bedouelle, Le Quincuplex Psalterium de Lefèvre d'Etaples. Un guide de lecture, Genebra, 1979 (com abundante bibliografia); J. LefÈvre d'Etaples, Quincuplex Psalterium. Fac-similé de l'édition de 1513, ed. por G. Bedouelle, Genebra, 1979. 
completo com os sistemas e sistematizações de origem escolástica e com qualquer tipo de pretensões especulativas, e teve da mensagem cristã uma visão acentuadamente universalista. O evangelismo francês caracterizou-se, em contrapartida, por uma atitude mais sentimental e por uma visão da teologia de feição mais pietista, em que a Bíblia constituia a sua fonte por excelência. No fundo, porém, quer um quer outro desejavam levar a cabo uma profunda reforma das instituições e da vida religiosa.

As reacções integristas contra erasmistas e fabristas não se fizeram esperar. Depois da explosão luterana, o evangelismo e o humanismo cristão foram julgados como uma forma de cripto - ou proto-luteranismo. Paris, Lovaina e Colónia impuseram-se como os principais focos dessa resistência contra estas correntes. O que sucedeu a Dolet (16) por parte da Sorbonne e as frequentes polémicas movidas por Cousturier (17), Bedier, Leclerq, Egmondanus e Latomus (18) traduzem

(16) Étienne Dolet, humanista e polemista célebre, nasceu em Orléans em 1508, e faleceu em Paris, em 3 de Agosto de 1546. Tornou-se famoso o conflito havido entre Dolet e Erasmo, em 1535. Defendeu o uso da Bíblia em vernáculo e teve grandes problemas com a Inquisição. Foi declarado herege pela Faculdade de Teologia de Paris e condenado à morte pelo parlamento da cidade. Contrariamente ao que tantas vezes se afirma, pode dizer-se que Dolet não foi ateu. - Escreveu: Commentarii linguae latinae, 2 vols., Lião, 1536-1538; Formulae latinarum locutionum illustrium, ibid., 1539; Dialogues de Platon, ibid., 1545. - Sobre Dolet, vid. M. ChasSaIGne, Étienne Dolet, Paris, 1930; Сh. Perrat, in Bibliothèque d'Humanisme et de la Renaissance, 4 (1944), 138-143; L. FÈBVRE, ibid., 6 (1945), 98-170; Catholicisme, III, 970 ss.; Dictionnaire d'Histoire et de Géographie Eclésiastiques, XIV, 574-577.

(17) Vid. sobre Cousturier (Sutor): P. S. ALLEN, Opus epistolarum D. Erasmi, VI, Oxford, 1926, 132 (cf. o vol. de indices); Dictionnaire de Théologie Catholique, III, 1987 s.; R. G. VIlloslada, La Universidade de Paris..., Roma, 1938; Enciclopedia Cattolica, IV, 793; G. Schurhammer, Franz Xaver, I, Francoforte, 1955; Dizionnario Ecclesiastico, III, 1020. - Principais obras de Cousturier: De vita cartusiana, Paris, 1522; De triplici connubio d. Annae, ibid., 1523; De tralatione Bibliae et novarum interpretationum reprobatione, ibid., 1524; Antapologia, ibid., 1526; Apologecticum in novos Anticomaritas, ibid., 1526; In dainnatam Lutheri haeresim, ibid., 1531; De potestate Ecclesiae in occultis, ibid., 1534.

(18) Jacobus Latomus (Jacques Masson) foi um dos teólogos de controvérsia mais famosos do seu tempo. Exerceu também o cargo de inquisidor. Entrou em polémica com Erasmo, tendo escrito a propósito De trium linguarum et studii theologici ratione dialogus (Antuérpia, 1519). Atacou igualmente os reformadores, Lutero, Oecolampadius e Tyndale. Como escreve J. Etienne: «Seine Werke lassen 
de forma bem eloquente a vigorosa oposição criada à volta do evangelismo e do humanismo cristão.

Também em Espanha, se ergueram vozes de vários lados contra Erasmo e Lefèvre. Zuñiga (19) falava do luteranismo básico da filosofia humano-evangelista, e Carranza de Miranda (20),

aul eine Neigung zur Poleik schliessen; die Wahl der von ihm behandelten Probleme ist durch seine Gegner bedingt. Er war jedoch unfähig, die Anliegen der evangelischen Bewegung und des Reformhumanismus zu erfassen, empfand nur das Gefährliche solcher Tendenzen und übersah die darin enthaltenen Erneuerungsmöglichkeiten». - Sobre Latomus, vid. H. DE JONGH, L'ancienne faculté de théologie de Louvain au premier siècle de son existence, Lovaina, 1911; R. GuelluY, "L'évolution des méthodes théologiques à Louvain d'Érasme à Jansénius», in Révue d'Histoire Ecclésiastique, 37 (1941), pp. 52-71; H. DE VоCHT, History of the Foundation and the Rise of the Collegium Trilingue Lovaniense 1517-50, II-III, Lovaina, 1953-1954; J. ÉTIENNE, Spiritualisme érasmien et théologiens louvanistes, Lovaina, 1956, XVIII-XIX, 163-186. - Obras de Latomus: Opera onnia, Lovaina, 1550; De tritun linguarum e De primatu pontificis adversus Lutherum, nova ed.: Bibliotheca reformatoria neerlandica, ed. de S. Cramer - F. PIJPeR, III, Haia, 1905, 28-84, 101-195.

(19) Sobre Zúñiga (Diego López de Zúñiga, ou Jacobus López Stunica), vid. HurTER, Nomenclator Literarius Theologiae Catholicae II, 1298 s.; P. KALKHOF, in Archiv für Reformgeschichte, 3 (1905-1906), pp. 70-83; A. BLUDAU, "Die ersten Erasmusausgaben des Neuen Testaments und ihre Gegner», in Biblische Studien, 7/5 (1902), pp. 125-140.

sobretudo o vol. XII (sob o nome Stunica). - As obras mais significativas de Zúñiga são as seguintes: Itinerarium (da sua viagem para Roma), ed. por A. SсHотT, Hispaniae Bibliotheca, Francoforte, 1608, pp. 624-649; Correspondência com J. de Vergara, ed. de P. S. Allen, IV, pp. 623-631; Annotationes contra Erasmum Roterodamum in defensionem traslationis Novi Testamenti, Alcalá, 1520; Erasmi Roterodami blasphemiae et impieates nunc primum propalatae ac proprio volumine alias redargutae, Roma, 1522; Apologia Ecclesiasticae translationis quos illi Erasntus Roterodamus impegerat, s.l., n.d.; Loca quae ex Stunicae annotationibus, illius suppresso nomine, in tertia editione Novi Testamenti Erasmus emmendavit, s.l., 1524; Libellus trium illorum voluminum praecursos, quibus Erasmicas impietates ac blasphemias redarguit, Roma, 1522; Conclusiones principaliter suspectae et scandalosat quae reperiuntur in libris Erasmi Roterodami, ibid., 1523.

(20) Sobre Bartolomeu Carranza de Miranda, vid. QuÉTIF-ÉCHARD, 1I, 236-243; Catholicisme, II, 592 ss. (com bibliografia); V. Beltrán de Heredia, Las corrientes de espiritualidad entre los Dominicos..., Salamanca, 1941, pp. 110-156; G. MARAÑon, «El proceso del Arzobispo Carranza», in Boletin de la real Academia de la historia, 127 (Madrid, 1950), pp. 136-178; J. I. TelecheA, «El "Articulus de justificatione" de Carranza», in Revista Española de Teologia, 15 (1955), pp. 563-636; ID., «Dos textos teológicos de Carranza», in Anthologia Annua, 3 (Roma, 1955), pp. 621-707; ID., «El formulario de visita pastoral de Carranza», ibid., 4 (1956), pp. 385-437. - Obras de maior relevância de Carranza: De necessaria residentia episcoporum..., 
Carvajal (21) e Maldonado (22), associando-se a grande número de membros de ordens religiosas, moviam-lhes igualmente campanhas implacáveis. Alguns, como Gudiel, Cantalapiedra (23) e Luís de

Veneza, 1547; Summa Conciliorum... Quatuor controversiae (De auctoritate Ẽclesiae, Scripturae, Concilii, Papae), ibid., 1546; Comentarios sobre el cathecismo christiano, Antuérpia, 1558. Dele se conservam vários trabalhos manuscritos sobre a Suma de S. Tomás, a Missa, a justificação e a graça, a Sagrada Escritura, a Ascese e a Pastoral, que têm sido objecto de importantes investigações de J. I. Telechea IDIGoras.

(21) Sobre Luis de Carvajal, vid. Marcel Bataillon, Erasmo y España, op. cit.; V. Beltrán de Heredia, sobre aquela obra, in Ciencia Tomista, 57 (1938), pp. 544-582; B. ORomi, Verdad y vida, 3 (Madrid, 1945), pp. 682-690; Dictionnaire d'Histoire et de Géographie Ecclésiastiques, XI, 1242 (com bibliografia); H. JEDIN, Geschichte des Konzils von Trient, II, 386, 392, 522s. - As obras mais relevantes de Carvajal são as seguintes: Apologia monasticae religionis diluens nugas Erasmi, Salamanca-Paris, 1528; Dulcoratio amarulentiarum Erasmicae responsionis ad Apologiam Fratris Ludovicci Carvajal, Paris, 1530; Declamatio expostulatoria pro Inmaculata Conceptione, Sevilha, 1533; Paris, 1541; De restituta theologia liber unus, Antuérpia, 1548; Oratio habita in concilio Tridentino, ibid., 1548; De vero matrimonio regum Angliae (ms. no British Museum, Add. 28, 583, fol. 70-100).

(22) Sobre Juan Maldonado, vid. Marcel Bataillon, Erasmo y España, op. cit., passim. - Os trabalhos de Maldonado mais conhecidos são: Eremitae (continuação das Exercitationes linguae latinae de Luis Vives); Hispaniola, Burgos, 1535; Opuscula quaedam docta simul et elegantia (De senectute christiana; Paradoxa; Ludus chartarum Tridunus et alii quidam; Geniale judicium, sive Bacchanalia), ibid., 1549; Id., com a obra Pastor bonus também, ibid., 1549; Quaedam opuscula nunc primum in lucem edita (De foelicitate christiana; Praxis sive di lectione Erasmi; Somnium; Ludus chartarum Tritumphus; Desponsa calta), ibid., 1541.

(23) Sobre estes autores, vid. Marcel Batall lon, Erasmo y España, op. cit. Cantalapiedra, além de Institutiones in linguam sanctam Paris, 1548; Salamanca, 1570, ed. em que foram incluidas as Chaldaicarum Institutionum, 3 liv., escreveu a célebre obra Libri decem Hypotyposeon theologicarum sive regularum ad intelligendum Scripturas Divinas, «in quo ex SS. Patribus Hebraeorumque scriptis ea omnia congessit, quae ad rectam Sacri Codicis intelligentiam aliquo modo conferre possent. Dignus proinde qui ex eodem ordine cum Sixto Senensi decertet, quem, rabbinica eruditione inferior, Patrum cognitione aequalis, theologica institutione longe superat. Prima tamen operis editio in indicem relata est, quod in causa esse videtur, cur hic noster debita sibi laude in historia exegeseos caruerit» (SimON-Prado, Praelecciones Biblicae, Turim-Roma-Madrid, 1954, p. 390). Acerca desta obra notável de Cantalapiedra, comentou L. Juan García: «Son las Hypotyposes un libro de valor enorme, de los que hacen época en la historia de los estudios bíblicos, y mui especialmente de la Hermenéutica, de la cual constituyen un monumento superior a todo lo publicado antes, dentro y fuera de España, por su pasmosa erudición y claridad, por su extensión y tendencia enteramente científica y fundada con acierto - de ordinario en la Biblia, en los Padres y en los expositores eclesiásticos, por la frequente y oportuna 
León (24), porque adeptos das ideias erasmianas, viram-se mesmo envolvidos em grandes dificuldades com a inquisição.

A tudo isto o roterdamês não deixava de responder, procurando silenciar as críticas que lhe eram dirigidas. Sintomático é o que escreveu a esse propósito nas Hyperaspites: «Tudo o que dizemos, tudo o que fazemos, serve de base para a suspeita. Sobre tal problema, cuja discussão era livremente permitida a escolas opostas, não se nos consente mais o abrir a boca. Esta escravatura, que vós julgáveis abolir, pesa hoje sobre nós».

Não admira que Erasmo tivesse sido acusado de herege, o que o levou também a defender-se com vigor, tendo mesmo escrito obras contra Lutero (25) e Melanchton, que o haviam atacado duramente.

utilización de los autores profanos, y hasta por el mismo lenguaje pulido, precioso y elegante, digno de un renacentista. Sus cien reglas para la interpretación forman un riquíssimo arsenal, a donde, ya directa, ya indirectamente, fueron a surtir-se - lo confesaran o no los primeros que lo hicieron - cuantos ha aplicado su ingenio a tan penosa labor" (Los estudios biblicos en el siglo de oro de la universidad Salmantina, Salamanca, 1921, p. 21).

(24) Sobre Luís de León, vid. A. GuY, La pensée de Fray Luis de León, Paris, 1943; K. Vossier, Munique, 2." ed., 1946; D. Alonso, Poesia española, Madrid, 1950; S. Muñoz Iglesias, Fray Luis de Léon teólogo, ibid., 1950; Enciclopedia Cattolica, VII, 1113 s.; A. G. VeIGA, in «G. Diaz-Plaja», in Historia General de las lileraturas hispánicas, II, Barcelona, 1951, 541-656 (com bibliografia). - As obras mais importantes de Luís de León são: Traducción literal y declaración del libro de los Cantares de Salomón (escrita em 1571; publicada em Salamanca, em 1798); La perfecta casada, ibid., 1583; De los nombres de Cristo, ibid., 1583-1595; Exposición del libro de Job, Madrid, 1779. Acerca dos escritos do grande humanista castelhano, escreve W. Kellermann: «...durchdringen sich exegetisches Denken, Renaissance-Form und neuzeitliche FIömmigkeit in einzigartiger Synthese. Die Lyrik, mitten im theologischen Kampf gereift gibt Leons Sehnsucht nach dem ewigen Reich und dem Frieden des einfachen Lebens in genialer Schönheit der Idee und Sprache kund" (in Lexicon für Theologie und Kirche, 6, 963).

(25) Como escreve Will Durant acerca de Lutero: «Je grösser Luthers Glaubengewissheit und Macht wurden, desto mehr nahm seine Toleranz ab und desto strenger wurde sein Dogmatismus. Sein ursprünchlicher Standpunkt, dass «Ketzerverbrennungen gegen den Heiligen Geist verstossen», ist von der Bannbulle Leos X. Exsurge Domine ausdrücklich als "Irrelehre» bezeichnet worden. In seinem Brief an den christlichen Adel deutscher Nation (1520) hatte er jeden Christen zum Priester ordiniert, ihm das Recht zugesprochen, die Bibel nach seiner persönlichen Einsicht und Erleuchtung zu interpretieren und hinzugefügt: "Szo solt man die ketzer mit schrifften, nit mit fewr ubirwinden». In seinem Traktat Uber dei weltliche Obrigkeit (1522) hiess es: «Das uber seele niemandt kan gewallt haben den Gott... Noch 
É certo que havia inúmeras semelhanças entre as concepçð̃es erasmianas e protestantes no que respeita a diversos aspectos teológicos, mas não é

faren itzt unser. Keysser und klùge fursten also unnd lassen sich Bapst, Bischoff und Sophisten dahyn fueren eyn blind den andern, das sie yhren unterthanen gepieten zú glewben on Gotiis wort, wie sie es gútt dunckt, unnd wollen dennoch christliche fursten heyssen... Ketzerey kan man nymer mehr mitt gewalt weren... willtu ketzerey vertreyben, sso mustu den griff treffen, das du sie fur allen dingen auss dem hertzen reyssest unnd grundtlich mit willen abewendest. Das wirst du mitt gewallt nicht enden, ssondern nur stercken. Ist ketzerey da, die uebrwinde man, wie sichs gepůrtt, mitt Gottis wort... Denn es ist eyn frey werck umb den Glauben, datzu man niemand kan zwingen» (LuTHER, Tischreden, vol. XI, p. 262 ss.). E mais adiante, diz: "Dic erste Phase der Intoleranz betraf die Juden... Es dürfte Luther bewusst gewesen sein, dass der Protestantismus in mancher Hinsicht einer Rückkehr zur mosaischen Religionsaufassung gleichkam, etwa in der Werschätzung des Alten Testaments, der Propheten und der Psalmen, in der Ablehnung des Priesterzölibats und des Ordenswesens und hinsichtlich der Forderung einer strafferen als der laxen katholischen Sexualmoral. Als die Juden dem Protestantismus trotzdem nicht entgegenkamen, war er enttäuscht; und von der Abneigung gegen Geldzinsen war es ein kleiner Schritt zur Feindseligkeit gegen den jüdischen Geldverleiher und von diesem gegen alle Juden. 1537, als Kurfürst Johann die Juden aus Sachsen auswies, baten sie Luther um seine Fürsprache, doch umsonst. In einem Tischgespräch warf er Juden und Papisten als gottlosen Geschmeiss zusammen... In seinen letzten Lebensjahren verfiel er in antisemitische Raserei und beschuldigte die Juden, ein halsstarriges, ungläubiges, stolzes, verdobenes, verabscheuungswürdiges Volk zu sein, dessen Schulen und Tempel durch Feuer von der Erde getilgt werden müssen) (WILl DURANT, Das Zeitalter der Reformation, vol. IX de Kulturgeschichte der Menschheit, trad. alemã, Munique, 1978, p. 431 ss.). E o mesmo autor dá outros exemplos da intolerância de Lutero e de outros reformadores. Os próprios governos sentiam-se na obrigação de perseguir os hereges: «Dem katholischen Vorbild folgend, fühlten sich auch protestantische Regierungen verpflichtet, für religiöse Einheitlichkeit zu sorgen... Die Protestanten übernahmen natürlich auch die von den Katholiken entwickelte Zensur der Druckerzeugnisse; so untersagte Kurfürst Johann von Sachsen auf Betreiben Luthers und Melanchtons die Veröffentlichung, den Verkauf oder die Lektüre zwinglianischer und täuferischer Schriften wie auch die Verkündigung ihrer Lehren (1528)»). O mesmo se diga da excomunhão. - Acerca das relações entre humanistas e reformadores, comenta ainda W. Durant: "Der unduldsame Dogmatismus der Reformatoren, die Gewaltsamkeit ihrer Sprache, due Aufsplitterung in sich befehdende Sekten, die Vernichtung der kirchlichen Kunst die Prädestinatonslehre, die Indifferenz gegen klassiche Überlieferung, die erneute Akzentuierung der Höllen — und Dämonnsvorstellungen, die Überbetonung des Seelenheils in einer Welt jenseits des Grabes - all das wirkete zusammen, um die Humanisten der Reformation zu entfremden». O Humanismo significou o regresso ao passado clássico; o protestantismo era o retorno humilde a S. Agostinho, ao cristianismo primitivo e até mesmo ao judaísmo do Antigo Testamento. $O$ antigo conflito entre a cultura hele- 
menos verdadeiro que profundas barreiras separavam o reformista de Roterdão do reformador de Wittenberg.

nística e a hebraica ressuscitava de novo agora. Os papas haviam não sô tolerado os humanistas como até os beneficiaram imenso. Contudo, não compreendiam muito bem que, especialmente, aquém dos Alpes alguns humanistas enveredassem por outros caminhos, preferindo a língua vernácula, escrevendo sobre temas estranhos às suas preocupações, como o inferno e a salvação da alma, etc. Como não entendiam as disputas entre Lutero e Eck, Lutero e Carlstadt, Lutero e Zwínglio que consideravam como coisa estéril, discussões vazias de sentído sobre questões que estavam mortas há muito. Muitos humanistas não sentiam qualquer interesse por assuntos de ordem religiosa: «Nach ihrer Auffassung war der Protestantismus ein Verrat an der Renaissance, die abermalige Anerkennung des Übernatürlichen, Irrationalem und Diabolischen, lauter Dinge, die das mittelalterliche Denken verdunkelt hatten; dies war für sich kein Fort -, sondern ein Rückschrift, war die neuerliche Unterwerfung des mündig gewordenen Geistes unter die primitive Vorstellungswelt der Massen». E diz ainda Will Durant: «Luthers Schmähungen der Vernunft, seine Lobpreisung eines Bekenntnisses, das die protestanischen Päpstlein erst noch zu definieren hatten, waren ihnen zutiefst zuwider. Was verblieb denn vom Adel des Menschen, den Pico della Mirandola so begeistert besang, wenn alles irdische Geschehen - jedes Heldentum, jedes Opfer und jede Entwicklung des Anstands und menschlichen Wortes ... lediglich den mechanischen Vollzug der nicht zu beugenden Ratschlüsse Gottes durch hilflose menschiliche Marionetten darstellte?»). Humanistas, como Wimpfeling, Beatus Rhenanus, Thomas Murner, Sebastian Brant criticavam, é certo, a Igreja, mas não se afastaram dela. E alguns que antes tinham aderido às ideias de Lutero vieram depois a distanciar-se dele à medida que a teologia protestante e a polémica ia ganhando maior volume. O helenista e homem de Estado Willibald Pirckheimer, que inicialmente defendeu abertamente Lutero de tal modo que foi incluído entre os excomungados pela bula Exsurge Domine, declarou depois sentir-se profundamente chocado pela língua bárbara de Lutero e veio a afastar-se da rebelião movida contra a Igreja. Döllinger na obra Die Reformation, vol. I, p. 533, transcreve um texto interessante sobre a posição de Pirckheimer do qual aqui deixamos um pequeno extrato: «Ich leugne nicht, dass mir im Anfange Luthers Unternehmen nicht ganz verwerflich erschien, wie denn keinem wohlgesinnten Manne die vielen Irrtümer und die vielen Betrügereien, die alImählich in die christliche Religion eingeschlichen, gefallen konnten. Ich hoffte daher, dass nun einmal diesen vielen Übeln abgeholfen würde; aber ich fand mich sehr getäuscht, denn bevor die früheren Irrtümer ausgerottet waren, drangen noch weit unerträgerlichere ein, gegen welche die früheren nur Spielereien waren. Ich fing daher an, mich allmählich zurückzuzichen, und je aufmerksamer ich alles betrachte, um so klarer bemerkte ich die List der alten Schlange, weswegen ich auch von vielen öfters Anfechtungen zu erleiden hatte. Von den meisten werde ich als Verräter an der evangelischen Wahrheit geschmäht, weil ich an der nicht evangelischen, sondern teuflischen Freiheit so vieler Apostaten, Männer wie Weiber, kein Gefallen finde, um von anderen unzähligen Lastern, die fast alle Liebe und Frömmigkeit vertilgt haben, gar nicht zu 
Erasmo, que não foi condenado na Junta de Valladolid (26), expressamente convocada para examinar as suas ideias, sentiu forte protecção

reden... Luther aber mit seiner frechen, mutwilligen Zunge verhehlt keinesfalls, was ihm im Sinne liegt, so dass er völlig in Wahnsinn verfallen oder vom bösen Greiste geleitet scheint.»

Mutian é outro exemplo que se pode apontar. A princípio saudou Lutero como «Morgenstern von Wittenberg». Depois viu nele um «Anstifter unseliger Verwüstung» e lamentou «die Verwegenheit und den unerträglichen Dünkel» dos mais novos. Crotus Rubianus, que nas Dunkelmännerbriefen se colocou ao lado de Lutero, regressou em 1521 ao seio da Igreja. Reuchlin escreveu a Lutero uma carta muito gentil e tentou evitar que Eck queimasse os escritos de Lutero em Ingolstadt, mas censurou Melanchton, seu sobrinho, pelo facto de este ter aceite a teologia de Lutero. E morreu como filho fiel da Igreja. Johannes Dobenek Cochlaeus, que a princípio simpatizou com Lutero, dirigiu-lhe em 1522 uma carta muito crítica: «Meinst du, dass Emser oder ich Sünde und Schande der Geistlichen wolle vertreten und verfechten? Da behüte uns Grott vor, wir wollten dir viel lieber dieselben helfen ausrotten, wo es Flug hätte und wir etwas vermöchten dazu zu tun. Aber Christus lehrt uns nicht den Weg, darauf du so hoch und gewaltig einhertrabst: mit Antichirst, Hurenhäusern, Teufelsnestern, Greueln und anderen anerhörten Schmähworten, dazu mit dem Schwert, nit Blut, mit blutigen Händen. O Luther, diesen Weg hat dich Christus mit Werken nie gelehrt» (Johannes Jansen, Geschichte des deutschen Volkes seit dem Ausgang des Mittelalters, vol. II, p. 248 s.). Foi impressionante o choque entre humanistas e reformadores nalguns casos. As críticas mútuas eram frequentes e bastante duras. Eoban Hess e e Ulrich von Hutten permaneciam fiéis aos ideais da Reforma. Foi célebre a polémica entre Erasmo e Hutten por causa da obra deste último, Expostulatio, contra a qual o roterdamês escreveu Spongia Erasmi adversus aspergines Hutteni. A morte de Hutten em 1523, em Ufenau (Lago de Eurique), depois de uma existência trágica, impressionou toda a gente. Em 1959 os seus restos mortais foram transladados para outro sítio e receberam as homenagens de protestantes e católicos. Sobre Hutten, vid. P. Kalkoff, Huten und die Reformation, Leipzig, 1920; ID., Hutens Vagantenzeit und Untergang, Wárzburgo, 1925; F. WALSER, Die politische Entwicklung Hutens während der Entscheidungsjahre der Reformation, Mainz-Berlim, 1928; D. CANTIMORI, Huten ed i rapporti tra Rinascimento e Riforma, Pisa, 1930; H. Drewinc, Vier Gestalten aus dem Zeitalter des Humanismus, St. Gallen, pp. 215-284; K. Buchner, Die Freundschaft zwischen Huten und Erasmus, Mainz, 1948; H. G. KELlER, Huten und Zwingli, Aarau, 1952; e artigos in Enciclopedia Cattolica, VI, 1517 s.; Religion in Geschichte und Gegenwart, 3." ed., III, 496 s.; Catholicisme, V, 1113 s.; Lexicon für Theologie und Kirche, V, 549-550.

(26) A Assembleia de Valladolid teve lugar entre 27 de Junho e 13 de Agosto de 1527. Foi convocada pelo inquisidor-mor, D. Alonso Manrique, e tinha como objectivo a análise teológica do pensamento erasmiano. Entre os presentes, contavam-se Pedro Ciruelo, Bernardina Vásquez de Oropesa, Fr. Diego de Astudillo, Fr. Antonio de Guevara, Sancho Carranza de Miranda, Alonso de Virués, Pedro de Lerma, Luis Coronel, Francisco de Vitoria e os portugueses Pedro Margalho, 
por parte da cúria romana, da chancelaria imperial e da corte de França. Isto explica-se, por um lado, porque existia uma manifesta prudência daquelas instâncias por causa da heresia luterana, mas também não deve esquecer-se que a ideia de restauração católica se instalara em muitos espíritos, devendo sublinhar-se, nomeadamente, que as ideias erasmianas haviam influenciado em larga escala os fautores do irenismo,

os D. Estêvão de Almeida e Diogo de Gouveia Sénior. Eram ao todo cerca de trinta os pontos de vista de Erasmo estavam já fortemente divulgados em Espanha por aquele tempo. A Querella Pacis, o Enchiridion militis christiani, os Colloquia e outros trabalhos do humanista flamengo eram conhecidos por grande número de pessoas. Há textos que referem essa profusão das obras do roterdamês. Assím Alfonso de Valdés afirmou a Maximiliano Transilvano que era um dos expoentes mais destacados da chancelaria imperial: "No hay en España mercancia de tanto despacho como las obras de Erasmo». Marcel Bataillon dedica ao tema da Assembleia de Valladolid um extenso e pormenorizado capítulo sobre esta ques tão (Erasmo y España, op. cit., pp. 226-278). Aí aborda os diversos aspectos que se relacionam directamente com a referida convocação: o messianismo imperial; a chancelaria de Carlos V, sua política antiromana e suas relações com Erasmo; o perigo turco e as Cortes de Valladolid; os frades espanhóis contra Erasmo; elaboração de uma lista de proposições erasmianas suspeitas de heresia; atmosfera criada pela notícia do saque de Roma; forças presentes da conferência teológica de Valladolid; discussão do primeiro capítulo do elenco de proposiçôes: Erasmo e a Santissima Trindade; o tema da divindade de Cristo; a divindade do Espírito Santo; a inquisição da heresia; suspensão da conferência; vitória dos partidários de Erasmo; sua consolidação pelo grupo erasmiano de Palencia e de Burgos. E a concluir: a carta imperial de 13 de Dezembro, garante da ortodoxia de Erasmo. Escreve a certa altura Bataillon: «Así, pues, España vivirá en un statu quo. Victoria, en un sentido, para los partidarios de Erasmo, puesto que lo que se tiene por sedicioso es la propaganda antierasmiana. Pero victoria que ellos sienten frágil, de la cual, por supuesto, no quieren abusar. Sin duda, ha corrido el rumor - hasta Brujas ha llegado - de que, no contentos con defender a Erasmo, atacan a los mantenedores de la escolástica, y de que han pedido que se espulguen las obras de Santo Tomás y de Escoto de la misma manera que se examinan las del hombre de Basilea. Vives, en carta a Vergara, se muestra naturalmente incrédulo con relación a semejante rumor; la noticia huele demasiado a pasquín. En realidade, los erasmistas clari* videntes no consideran el porvenir del pensaniento erasmiano con un optimismo $\sin$ mezcla de duda. Virués, aun antes de que la campaña de los frailes hubiese inquietado a la Inquisición, sugería a Erasmo la idea de una apologia general de sus escritos para asegurar su circulación póstuma: «en efecto - decía -, como tu bien sabes, por mucho tiempo que vivas, dejarás finalmente la tierra, y las órdenes monásticas no morirán nunca». Vergara mismo, durante la vela de armas de Valladolid, no pensaba $\sin$ inquietud en aquella miríada de emigos que se renovarían incesantemente cuando el Maestro hubiese muerto, y temblaba por la posteridad espiritual 
como os cardeais Seripando, Pole e Contarini e, por consequência, os colóquios de religião.

O evangelismo, o irenismo e o humanismo cristão mantiveram toda a sua pujança até ao pontificado de Paulo IV, mas com a falência do colóquio de religião de Ratisbona (1541) começaram a entrar em profunda crise, colmatada com o concílio de Trento que orientou as

de Erasmo, por sus libros. Un buen padre de familia - le escribía - debc pensar en el porvenir de sus hijos. Los teólogos de los siglos precedentes, que pertenecían a una orden monástica, han encontrado en esta orden defensores naturales y decididos de sus doctrinas. Pero, como sostener solo la lucha contra todas esas falanges conjuradas, "sobrc todo cuando lo que está en juego en el debate no son las intenciones segundas o los conceptos objectivos, sino la pitanza misma»? (Bataillon extrai as referidas citações de ALLEN, t. VI e VII). Valdés, Vergara e Virués e outros constituiram-se como que num estado maior do erasmismo espanhol, procurando defender as ideias de Erasmo a todo o transe. - Melquiades Andrés na sua obra La Teologia Española en el Siglo XVI, vol. II, pp. 270-291, ao tratar do erasmismo ou «philosophia Christi», ou via de cristianismo evangélico (1516-1535), aborda a questão do encontro do erasmismo e da reforma espanhola com os teólogos, com os autores espirituais, a liberdade franciscana e erasmista, a disputa sobre os ritos, as cerimónias e os religiosos, e a vida do cavaleiro cristão. Escreve acerca do encontro de Valladolid: "En Valladolid, amigos y adversarios convinieron en invirtarle (a Erasmo) a suprimir o a matizar algunas frases confusas desde el punto de vista de la ortodoxia. Sánchez Ciruelo, de acuerdo con su peculiar progresismo complutense, considera retroceso el hablar impreciso de Erasmo en una edad que se distingue por ser más entendida y perfecta que las anteriores». E cita depois um juizo ponderado e equilibrado de Francisco de Vitoria: «Es muy probable que todas las frases que se reprochan en Erasmo sean entendidas por él en el sentido más católico; y esto es creíble. Pero de ello no es de esperar nada bueno para la consolidación de la fe, e pueden perjudicar en gran manera a la fe de los flacos, de los irreflexivos o de los jóvenes. En effecto, al leerlas pueden verse llevados a dudas diversas, y a decirse que las verdades de la fe no están quizá tan bien estabelecidas como hasta entonces lo habían creído. No hay que perder de vista el escándalo dado así a los humildes, $y$ es preciso evitar que semejantes asuntos anden de boca en boca, lo cual no es posible sino a condición de suprimir o corregir esas frases de Erasmo y otras parecidas. $Y$ yo creo que Erasmo mismo no me tomará a mal el haberlo dicho» (p. 278; este texto é também citado por Bataillon, op. cit., p. 225). E comenta Melquiades Andres que Vitoria afirma tal coisa com dor, pois conhecia o que era uma ditadıra intelectual, a força dos amigos de Erasmo na corte e também a dos adversários, o peso da inquisição que então era fávorável ao humanista flamengo. Falou com o sentido de amor à verdade. Achamos exagerada a afirmação do autor quanto ao parecer de Vitoria, de Sánchez Ciruelo e de outros catedráticos de teologia de várias Faculdades como tendo contribuído para a diminuição do prestígio de Erasmo como teólogo nos ambientes universitários espanhóis. E diz mais que a vitória 
suas actividades no sentido das definições doutrinais e da polémica antiprotestante, em vez de enveredar pelo caminho das reformas que tanto haviam sido preconizadas. Isto não significa que as teses integristas de 1520 tivessem subsistido inalteradas até 1550. Com efeito, enquanto uns, como Latomus e Zúñiga, se opunham tenazmente a qualquer tipo de associação das belas letras à escolástica, outros como Eck (27)

que os seus amigos alcançaram consistiu em interromper a reunião para evitar o pior. Mas até 1530 o ritmo de edições e o apreço da corte mantiveram-se sem qualquer sintoma de abrandamento. Os processos erasmistas começariam depois e como o humanista deixou de ser, por antonomásia, o autor espiritual da via do evangelismo e do paulinismo, da caridade e da liberdade. Começou a ser considerado como humanista e exegeta e a ser menos lido ou, pelo menos, com grande cautela. Diz Melquiades Andrés que só interessavam sob o ponto de vista espiritual e prático, o Enquiridion e a Paraclesis, e sob o aspecto exegético, as suas Parafrasis ao Evangelho, recomendadas por S. João de Ávila. E a prova do que acaba de dizer, são as poucas citações de Erasmo nos grandes teólogos que iniciaram o seu magistério ou se formaram na década erasmista: Vitoria, Domingo de Soto, Juan de Medina, Melchor Cano, Alfonso de Castro, Andrés Vega, etc. E o mesmo sucedeu com os autores espirituais da década de 1530 e das três seguintes. Os ataques à Escolástica, a doutrina do Corpo Mistico, da interioridade, do valor da oração intelectiva em oposição à oração vocal, o regresso às fontes da revelação, a natureza da teologia como sabedoria, escreve o mesmo autor, são comuns aos reformistas espanhóis e viriam a impor-se na teologia contemporânea. Achamos esta posição de Melquiades Andrés um tanto exagerada e carecida de uma explicação mais cabal para entender o declínio do erasmismo. Houve factores decisivos para tal declínio que não se podem omitir, como a confusão com as ideias dos reformadores e a atitude do concílio de Trento quanto a certos temas. A conclusão que tira é no mesmo tom e, quanto a nós, merecedora igualmente de uma clarificação: «Pero a partir de 1530-1533, por causa de clarificación de muchos temas, del desgaste y pérdida de novedad del sistema, de los cambios de la política imperial, de los alumbrados, que buscaron defensa fácil en las obras y espiritu del Roterdamense, y por otros motivos, el erasmismo dejó de ser la bandera de la crítica donosa de las lacras del catolicismo, su interioridad quedó superada por otras vias espirituales autóctonoas, y su evangelismo, incorporado al movimiento bíblico. Unos cuantos temas y actitudes suyas enriquecieron positivamente nuestra cultura, especialmente en el campo de la exegesis. Pero la universidad, la espiritualidad y la política, en conjunto, caminaron por otros derroteros» (p. 279). Na sua obra Études sur l'humanisme Marcel Bataillon tratou dos pontos de vista dos portugueses presentes em Valladolid (pp, 18-45).

(27) Johannes Eck (Johannes Maier, Mayer) foi outro grande teólogo de controvérsia do séc. XVI, tendo-se tornado um dos maiores adversários da Reforma. Como professor e escritor grangeou enorme reputação nos meios cultos do seu tempo. E. ISERLOCH caracteriza assim o pensamento de Eck: «In seiner theologischen Methode ist Eck nicht der Erzscholastiker und unbedingte anwalt des Alten, als der er gew- 
suas actividades no sentido das definições doutrinais e da polémica antiprotestante, em vez de enveredar pelo caminho das reformas que tanto haviam sido preconizadas. Isto não significa que as teses integristas de 1520 tivessem subsistido inalteradas até 1550. Com efeito, enquanto uns, como Latomus e Zúñiga, se opunham tenazmente a qualquer tipo de associação das belas letras à escolástica, outros como Eck (27)

que os seus amigos alcançaram consistiu em interromper a reunião para evitar o pior. Mas até 1530 o ritmo de edições e o apreço da corte mantiveram-se sem qualquer sintoma de abrandamento. Os processos erasmistas começariam depois e como o humanista deixou de ser, por antonomásia, o autor espiritual da via do evangelismo e do paulinismo, da caridade e da liberdade. Começou a ser considerado como humanista e exegeta e a ser menos lido ou, pelo menos, com grande cautela. Diz Melquiades Andrés que só interessavam sob o ponto de vista espiritual e prático, o Enquiridion e a Paraclesis, e sob o aspecto exegético, as suas Parafrasis ao Evangelho, recomendadas por S. João de Ávila. E a prova do que acaba de dizer, são as poucas citações de Erasmo nos grandes teólogos que iniciaram o seu magistério ou se formaram na década erasmista: Vitoria, Domingo de Soto, Juan de Medina, Melchor Cano, Alfonso de Castro, Andrés Vega, etc. E o mesmo sucedeu com os autores espirituais da década de 1530 e das três seguintes. Os ataques à Escolástica, a doutrina do Corpo Místico, da interioridade, do valor da oração intelectiva em oposição à oração vocal, o regresso às fontes da revelação, a natureza da teologia como sabedoria, escreve o mesmo autor, são comuns aos reformistas espanhóis e viriam a impor-se na teologia contemporânea. Achamos esta posição de Melquiades Andrés um tanto exagerada e carecida de uma explicação mais cabal para entender o declínio do erasmismo. Houve factores decisivos para tal declínio que não se podem omitir, como a confusão com as ideias dos reformadores e a atitude do concílio de Trento quanto a certos temas. A conclusão que tira é no mesmo tom e, quanto a nós, merecedora igualmente de uma clarificação: «Pero a partir de 1530-1533, por causa de clarificación de muchos temas, del desgaste y pérdida de novedad del sistema, de los cambios de la política imperial, de los alumbrados, que buscaron defensa fácil en las obras y espíritu del Roterdamense, y por otros motivos, el erasmismo dejó de ser la bandera de la crítica donosa de las lacras del catolicismo, su interioridad quedó superada por otras vias espirituales autóctonoas, y su evangelismo, incorporado al movimiento bíblico. Unos cuantos temas y actitudes suyas enriquecieron positivamente nuestra cultura, especialmente en el campo de la exegesis. Pero la universidad, la espiritualidad y la política, en conjunto, caminaron por otros derroteros» (p. 279). Na sua obra Études sur l'humanisme Marcel Bataillon tratou dos pontos de vista dos portugueses presentes em Valladolid (pp. 18-45).

(27) Johannes Eck (Johannes Maier, Mayer) foi outro grande teólogo de controvérsia do séc. XVI, tendo-se tornado um dos maiores adversários da Reforma. Como professor e escritor grangeou enorme reputação nos meios cultos do seu tempo. E. ISERLOCH caracteriza assim o pensamento de Eck: «In seiner theologischen Methode ist Eck nicht der Erzscholastiker und unbedingte anwalt des Alten, als der er gew- 
e Driedo (28), aceitavam as técnicas filológicas do humanismo como factores e dados de cultura, embora rejeitassem a assimilação do humanismo cristão à ortodoxia católica.

öhnlich hingestellt wird. Wie in der Wirtschaftsethik suchte er auch in der Theologie modern zu sein und durch ausgiebige Berücksichtigung der Heiligen Schrift und der Väter dem Zug der Zeit nach Quellenähe gerecht zu werden. In diesem Sinn gehört er durchaus zu den Eahnbrechern einer positiven Theologie. Allerdings will er meist mehr durch die Fülle der angeführten Texte imponieren, als dass er zu einer schöpferischen Begegung mit ihnen kommt und sie religiösisch und theologisch fruchtbar zu machen versteht. Angesichts der dogmatischen Unklarheit der Zeit war es Ecks Verdienst, in Klarheit, ja Schärfe aufgewiesen zu haben, dass Luther nicht Reform, sondern Revolution bedeutete und auch später jeden Kompromiss auf Kosten der Wahrheit abgelehnt zu haben. Dabei bleibt die Frage, ob er aus Verantwortung um die Einheit sich genügend um seinen Gegner bemüht oder, etwa in Leipzig, ihn durch seine Schärfe erst zu seinen häretischen Konsequenzen getrieben und auf den Irrtum festgelegt hat. Der formalen Gewandtheit und der Fülle des Wissens entsprach nicht die religiöse und theologische Tiefe. So hat er wohl auch an seinem Sckicksal, einen faulen Frieden stören zu müssen, nicht allzu schwer getragen" (in Lexicon fïr Theologie und Kirche, III, 643-644). - Sobre Eck é vasta a bibliografia existente, podendo ser indicada a seguinte: H. SCHAUERTE, Die Busslehre des Johannes Eck, Münster, 1919; P. Polman, Die polemische Methode der ersten Gegner der Reformation, Münster, 1931; ID., L'Élément historique dans la controverse religieuse du XVI ${ }^{a}$ siècle, Gembloux, 1932; E. IsERLOH, Die Eucharistie in der Darstellung des Johannes Eck, Münster, 1950; ID., Der Kampf um die Messe in den ersten Jahren der Auseinandersetzung mit Luther, Münster, 1952; F. ZoEPFL, Johannes Eck: Lebensbilder aus dem Bayerischen Schyaben, Munique, 1958, 186-216; E. IsERLOH, art. in Lexicon für Theologie und Kirche, III, 642-644 (com bibliografia). - As principais obras de Eck encontram-se publicadas no Corpus Catholicorum, 16 (1930) LXXI-CXXXI, por J. MetzLer; nova ed. in Corpus Catholicorum 1 (1919), 2 (1921), 6 (1923), 13 (1928), 14 (1929); o Enchiridion locorum comnunium adversus Lutherum et alios hostes Ecclesiae (1525-1543) foi editado na mesma série em 1979.

(28) Johann Driedo(ens) foi outro teólogo notável do séc. XVI que se ocupou das questões levantadas por Lutero. Escreveu De ecclesiasticis scripturis $\ell$ l dogmatibus (Lovaina, 1533) sobre o método teológico e De captivitate et redemptione generis humani (ibid., 1534) sobre o mistério da salvação. Deixou ainda outras obras sobre a graça e a predestinação que só chegaram a ser publicadas depois da sua morte. Como escreve R. Aubert: ( Die Struktur dieser Werke ist oft mehr biblish als scholastisch. Driedo war einer der wenigen Theologen des 16. Jh., die gleichzeitig echte Treue zur Tradition und Empfänglichkeit für neue Orientierungen beweisen». Como bibliografia, apresentamos esta: H. DE Vocht, Monumenta humanistica lovaniensia, Lovaina, 1934; J. ÉTieNNE, Spiritualisme érasmien et théologiens louvanistes, ibid., 1956; Dictionnaire d'Histoire et de Géographie Ecclésiastiques, XIV, 795 ss.; Dictionnaire de Spiritualité Ascétique et Mystique, III, 1717 ss.. Sobre a obra De ecclesiasticis scripturis et dogmatibus: R. DRAGUET (Einfluss auf das Tridentinum), in 
Se é certo que o humanismo foi, como diz Toffanín, o bode expiatório do concílio de Trento, não deixa também de ser verdade que ele saíu triunfador daquela assembleia eclesiástica, na medida em que foi aceite como propedêutica do espírito e enquanto conjunto de técnicas científicas auxiliares.

Para não falar de outras causas que provocaram o fracasso do humanismo cristão, sublinhe-se apenas que, mais ainda do que a argumentação do integrismo, foram as metamorfoses do contexto político europeu e o facto de, ao contrário do protestantismo, nunca ter sido um movimento de massas, que contribuiram para o seu insucesso.

\section{PENETRAÇÃO DO huMANisMo EM PORTUGAL (29)}

A presença de estrangeiros letrados em Portugal constituíu um factor importante para a penetração do humanismo no nosso país. Entre eles, distinguiram-se João Petit, João Vaseu, Arnaldo Fabrício

Miscellanea historica in honore A. DE MEYER, Lovaina, 1946, 836-854; B. EMMIL, (Einfluss auf das Tidentinum), in Ephemerides Theologicae Lovanienses, 25 (1949), 588-599; J. Lodrioor, ibid., 26 (1950), 37-53; T. DHANIS, in (1949), 588-599; J. J. LODRIOOR, ibid., 26 (1950), 37-53; T. DHANIs, in Revue d'Histoire Ecclésiastique, 51 (1956), 454-470. - As obras de Driedo foram publicadas em conjunto, em 4 vols.: Lovaina, 1547-50, 1550-56; 1566-72.

(29) Sobre o humanismo em Portugal, vid., entre outros, Marcel Bataillon, Erasmo y España, op. cit.; ID., Études sur le Portugal au temps de l'humanisme, Coimbra, 1952; A. DA Costa Ramalho e J. DE CAstro Nunes, Catálogo dos mss. da Biblioteca Geral da Universidade de Coimbra relativos à Antiguidade Clássica, Coimbra, 1945; A. DA Costa RAmalho, Estudos sobre a época do Renascimento, ibid., 1969; ID., Estudos sobre o século XVI, ibid., 1980; JoAquim DE CARVALHo, Estudos sobre a cultura portuguesa do século XVI, 2 vols., ibid., 1947-1948; Luís DE MATOS, Les Portugais à l'Université de Paris entre 1500 et 1550, ibid., 1950; ID., Les Portugais en France au XVI ${ }^{e}$ siècle. Études et documents, ibid., 1952; ID., "Das relações entre Erasmo e os Portugueses», in Boletim Internacional de Bibliografia Luso-Brasileira, Lisboa, 1963; A. José SARAIVA, História da cultura em Portugal, vol. II, Lisboa, 1955, pp. 508-687; J. S. DA SILvA Dias, Correntes de sentimento religioso em Portugal, t. I, 2 vols., Coimbra, 1960; ID., A politica cultural da época de D. João III, vol. I, 2 ts., ibid., 1969; ID., Portugal e a cultura europeia (séculos XVI a XVIII), ibid,, 1953; J. V. DE PINA Martins, O Livro Português do Reinado de D. Manuel I, ibid,, 1970; ID., «Sobre o conceito de Humanismo e alguns aspectos histórico-doutrinários da cultura renascentista", in Arquivos do Centro Cultural Português, II, Paris, 1970; ID., «O Humanismo ita- 
e os catedráticos chamados pelo Rei Piedoso para leccionarem na Universidade e no Colégio das Artes.

Assistiu-se também, por outro lado, à ida de muitos portugueses para diversos países europeus, enviados como bolseiros quer pelos governantes, quer pelos seus superiores hierárquicos. Nos principais centros culturais de então, como Salamanca, Paris, Bordéus, Lovaina, Florença, Bolonha e Pisa, ouviram as lições de mestres notáveis, como sucedeu com os filhos do chanceler-mor João Teixeira, Henrique Caiado, João Rodrigues de Sá de Meneses, Diogo Pacheco e Aires Barbosa, que, em Florença, foram discípulos de Ângelo Poliziano.

$\mathrm{E}$, assim, voltaram à pátria transformados pelo contacto com os arautos do humanismo literário e científico algumas das mais destacadas figuras da Igreja da época, muitos ensaístas de relevo e pedagogos célebres e grande número de filósofos, teólogos, artistas, jurisconsultos e literatos, que no estrangeiro conviveram com os expoentes mais famosos do pensamento europeu, como Erasmo, Luís Vives, Guilherme Budé, Melanchton, os cardeais irenistas, etc..

A corte de D. João III, pelo menos até 1550 , data em que as primeiras orientações do concilio de Trento chegaram a Portugal, deu franco acolhimento às novas ideias renovadoras do humanismo e às tendências do irenismo e do progressismo, embora nem sempre houvesse uma consciência perfeita dos limites existentes entre humanismo e classicismo, ou entre humanismo cultural e humanismo formal, ou entre humanismo literário e humanismo doutrinário.

Mas, mesmo antes de 1550 , é incontestável a presença do elemento conservador e, por vezes, até do elemento reaccionário na nossa vida pública, desde o início do reinado joanino, como aconteceu com Diogo de Gouveia Senior e os bispos palacianos.

O que se pode dizer, sem sombra de dúvida, é que por volta de 1527 , ano em que se deram dois acontecimentos importantes que chamaram as atenções gerais para a crise da Igreja e para o alcance da doutrina da escola humano-evangelista - a Assembleia de Valladolid e o saque de Roma - havia, entre nós, a ideia clara de que se verificara, na

liano e a sua irradiação na Europa», in Cultura Italiana, Lisboa, 1971 ; ID., Humanismo e Erasmismo na cultura portuguesa do século XVI. Estudos e Textos, Paris, 1973; ID, Pico della Mirandola e o Humanismo italiano nas origens do Humanismo português, Lisboa, 1964. Em quase todas as obras mencionadas encontra-se abundante bibliografia sobre o tema do humanismo em Portugal. 
Europa, uma transformação radical do pensamento e dos horizontes culturais. Ultrapassara-se a forma mentis medieval e rompera-se com a antiga ideologia político-religiosa, com a perspectiva eclesiástica da vida em sociedade e com a visão ritual do cristianismo.

Uma das grandes preocupações de D. João III, neste contexto, foi renovar a cultura portuguesa e reestruturar o sistema escolar do país, de acordo com as exigências humanísticas e renascentais. Em princípios do séc. XVI era muito acentuada a degradação do ensino, apesar da reforma de 1431, do empenhamento dos infantes D. Henrique e D. Pedro e dos novos planos de estudo manuelinos.

Entre as experiências realizadas no sector do ensino preparatório, merecem referência especial as feitas em Braga e em Évora, e nos Colégios de Belém e nos Mosteiros de Penha Longa e da Costa. Mas, como escreve o Prof. Silva Dias, tais ensaios não deram resultados de grande monta, em nada tendo contribuído para a transformação generalizada e eficiente da escola e do país, e não conduziram à europeização intelectual dos portugueses (A Política Cultural da Época de D. João III, vol. I, t. 2..$^{\circ}$, pág. 487).

Em Coimbra, o ensino preparatório foi objecto de profunda reforma no Mosteiro de Santa Cruz, graças em especial a Fr. Brás de Barros: foram convidados vários professores estrangeiros, deu-se à docência das línguas eruditas uma importância muito particular, abandonou-se o plano de estudos medieval e valorizou-se sumamente a literatura e a cultura clássicas, e tentou-se mesmo a leccionação da teologia.

Mas depressa se notou que a tendência política do Estado era fazer da cidade do Mondego um grande centro cultural da Península. Devido às inúmeras lacunas e carências de que o ensino em Santa Cruz (30) enfermava, surgiu a ideia da criação do Colégio das

(30) O mosteiro de Santa Cruz foi fundado graças à iniciativa do arcediago da sé de Coimbra, D. Telo. A primeira pedra foi lançada a 28 de Junho de 1131 e a vida da comunidade teve início a 24 de Fevereiro de 1132. Na sua criação intervieram de várias maneiras os bispos D. Maurício e D. Gonçalo, Afonso Henriques, João Peculiar, etc. As disputas entre o cabido e a mitra, por um lado, e o mosteiro, por outro, tornaram-se célebres e perduraram por muito tempo. Poucos anos após a sua fundação, já funcionava ali um hospital. As Crónicas Breves relatam diversos factos de interesse para a história do mosteiro, entre eles o facto de se ter tornado um centro importante de cultura e de possuit um riquíssimo património, em grande parte devido a doações. As duas grandes reformas, relativamente aos edifícios conventuais e na esfera espiritual, tiveram lugar no séc. XVI, e foram iniciadas por 
Artes (1547), animado do espírito mais vivo da linha avançada do humanismo cristão e idealizado como meio eficaz de renovação dos nossos costumes e da nossa cultura. Sobretudo dedicado ao ensino da filo-

D. Pedro Gavião (1507-1516) e continuadas por Fr. Brás de Braga, ficando suspensas quando da extinção do priorado-mor (1545). Entre os mestres que ali trabalharam então, contam-se Diogo e João de Castilho, Nicolau Chanterenne, João de Ruão, Boytac, Hodart, Marcos Pires e outros. E registaram-se muitas inovações a aquisição de valiosíssimas peças de arte. A Congregação agrupava 20 mosteiros, destacando-se os de S. Vicente de Fora, S. Salvador de Moreira, S. Salvador do Grijó, S. Simão da Junqueira, e S. Agostinho da Serra do Pilar. Em 1770 o seu número já estava reduzido a 13, dos quais foram então extintos 9, entre eles o de Grijó. Quando foi extinto em 1834, a Congregação de Santa Cruz só abrangia além da casa-mãe e do seu colégio da Sapiência, os mosteiros de S. Vicente de Fora e da Serra do Pilar, bem como o convento de Mafra, que havia sido confiado aos cónegos regrantes. Além das escolas catedralíticas que entre nós começaram a funcionar a partir da segunda metade do séc. XII, tiveram enorme acção as escolas monásticas a partir de finais do mesmo século, sobressaindo entre elas a de Santa Cruz, possivelmente anterior à de Alcobaça. Como escreve o Prof. António Cruz: "Quanto à "livraria de mão" da canónica conimbrigense, está apurado que nela foram integrados, pouco depois de $\mathrm{D}$. Telo e os seus companheiros aí se congregarem, alguns manuscritos provenientes de S. Rufo de Avinhão e outros preparados no próprio «escritório», denotando este facto a existência de uma escola de escribas que antecedeu, no funcionamento, regular, o magistério de várias disciplinas e com ele veio a conviver». E refere que entre os primeiros códices não havia apenas os que continham usos, regra e costumes codificados pelo abade de S. Rufo Lethbert de Cambraia e, sobretudo, os que arrecadavan textos de $\mathrm{S}$. Agostinho sobre os evangelhos de S. João, S. Mateus e S. Lucas e o Génesis, o Exameron e o De penitentia de S. Ambrósio, assim como o Pastoral de S. Gregório e a exposição de Beda sobre S. Lucas. E ainda uma cópia das Colações de Cassiano, outro dos onze livros da História Eclesiástica de Eusébio Panfílio Rufino; textos de Flávio Josefo, de Rábano Mauro, de S. Jerónimo, S. Bernardo, etc. Há quatro códices que se distinguem pela particularidade da escrita usada pelos copistas e que têm de ser colocados ao lado dos poucos manuscritos existentes em Portugal em letra visigótica: o Liber Comicum, as Colações de Graciano acima mencionadas copiadas por Fernando Garcia; o códice miscelâneo que abre com o texto Capitulaciones in Libro Eusebio e, finalmente, o que contém o Sancti Ambrosii Tractatus de Psalmo C. VIII, X (sic). De incluir nesta enumeração ainda obras de Isidoro de Sevilha, Ticónio, Papias, Pedro Comestor e, sobretudo, Hugo de S. Vitor que viria a exercer grande influência na ol ientação dos estudos claustrais. Em Santa Cruz foram também preparados certos códices depois oferecidos, com alfaias, à canónica de Cidade Rodrigo quando da sua fundação (1184-1196). Havia ainda outros códices de carácter mais geral, destinados ao estudo das disciplinas do Trivium e do Quadrivium. Nos inventários de 1207, 1218 e 1226, interpretado pelo Prof. António Cruz, encontram-se elementos importantes que permitem saber qual a matéria versada e que 
sofia e das humanidades, contou no início, entre os seus mestres mais famosos, ários professores vindos de França, os chamados «bordaleses».

muito contribuíu para a formação cultural de S. António, de S. Fr. Gil, e de outros escolares de Santa Cruz. Por eles se vê que a medicina, as ciências físicas, a astronomia, a retórica e outros domínios do saber eram cultivados no mosteiro dos crúzios. Nomes como Aljazar, na tradução de Constantino, o Africano, Razis, Isidoro de Sevilha, Alcabício, Marbode, Marco Túlio Cícero, Prisciano, Helpércio, Pedro de Musandino, aparecem representados nos referidos inventários. Entre os mestres sabemos, pelo códice Gemma corone, que D. Raimundo e D. Pedro Peres foram dos mais insignes da época. O primeiro era «mestre profundíssimo» em diversas ciências; o segundo bom pregador, «magno» em Gramática, Medicina, Lógica e Teologia, a ele se devendo o grande a vanço cultural atingido em Santa Cruz. Quanto aos segundo e terceiro quartéis do séc. XIII há poucas informações. - Sabe-se que foram então mandados estudar no estrangeiro muitos escolares para depois exercerem o magistério em Coimbra. O pedido da criação dum "Estudo Geral» na cidade do Mondego partiu de vários priores de congregações portuguesas entre eles o de Santa Cruz. Foi dirigido a Nicolau IV em 12 de Novembro de 1288 (para que houvesse em Portugal in qualibet facultate generale studium litterartim). Em 1464 ensinava-se em Santa Cruz ainda a Teologia a cargo do prior D. Jorge da Costa. D. João III restaurou os estudos em mosteiro crúzio em 1527 de acordo com Fr. Brás de Braga, a quem incumbira a reforma do mesmo. Para isso foram criados os colégios de S. Agostinho e de S. João, para o funcionamento de aulas, e mais dois para residência de estudantes. A actividade das novas escolas iniciou-se em 1534. Com a vinda da A actividade das novas escolas iniciou-se em 1534. Com a vinda da Universidade para Coimbra, em 1537, manteve-se nos colégios crúzios o ensino da Teologia, da Medicina, das Artes, da Gramática e do Grego. Havia assim em Coimbra duas Escolas superiores. Isto até que D. João III determinou que houvesse «uma só universidade e assim fosse chamada» (carta régia de 15 de Dezembro de 1540). E em 1544, por sugestão de Fr. Brás de Braga, os mestres do colégio de Santa Cruz foram incorporados na Universidade (carta régia de 22 de Outubro de 1544). Mas, apesar disso, continuou-se a ensinar em Santa Cruz a Teologia e as Humanidades para os membros da comunidade. Um dos grandes mestres do séc. XVI foi o célebre D. Pedro de Figueiró, autor de comentários bíblicos de notável merecimento. A livraria do colégio foi enormemente enriquecida e também se instalou ali uma tipografia, em que se impôs como impressor de renome Germão Galhardo. Sobre a biblioteca do mosteiro deixaram-nos informações preciosas Francisco de Mendanha e Jerónimo Román. Como diz o Prof. António Cruz: «O exame dos catálogos ou inventários que chegaram aos nossos dias, quando não dos próprios livros, manuscritos ou impressos, revela-nos que era opulenta a livraria conventual, na quantidade e qualidade dos exemplares que integravas. Contavam-se ainda por milhares, em 1834, quando da dispersão: códices medievais, incunábulos, edições as mais raras, e as que eram, ao tempo, as mais recentes e sumptuosas coleç̧ões de estampas». De referir a riqueza em textos musicais, e ainda a criação no mosteiro, em 1748, da Academia 
Também se impunha, e de maneira flagrante, uma profunda reforma da Universidade (31). D. João III, frustradas as tentativas da sua reestruturação, em Lisboa, e levado pelo conselho de Luís Vives, decidiu transferi-la para Coimbra, onde deu início a uma obra de total remodelação, renovando quase por completo o corpo docente (convidando professores estrangeiros e mandando formar outros lá fora), e transformando radicalmente 0 sistema pedagógico e os planos de estudo das diversas Faculdades.

A título de exemplo, para se ver como a corte joanina era sensível às directrizes culturais do humanismo no campo das ciências sagradas, lembremos o que se passou com a teologia. Procurando pô-la em dia

Litúrgica Pontificia, sob o patrocínio de Bento XIV e dirigida por D. Miguel da Anunciação, que foi o seu fundador. O Marquês de Pombal suprimiu-a em 1767. -- Sobre o mosteiro de Santa Cruz, vid. Nicolau de Santa Maria, Chronica da Ordem dos Conegos Regrantes, Lisboa, 1668; Timóteo dos MArtires, Crónica de Santa Cruz, sep. de O Instituto, 3 vols., Coimbra, 1955-1960; Paulo Merea, «Sobre o isento de Santa Cruz de Coimbra», in Brotéria, vol. XXXI (1940); Rui de Azevedo, Documentos falsos de Santa Cruz de Coimbra, Lisboa, 1932; ID., Estudos e Diplomática Portuguesa, Coimbra, 1938; M. Lopes de AlmeIda e MÁro BRANDÃo, A Universidade de Coimbra. Esboço da sua História, ibid., 1937; Márlo Brandão, Cartas de Frei Brás de Braga para os priores do Mosteiro de Santa Cruz de Coimbra, ibid., 1937; ID., Actas dos Capitulos do Mosteiro de Santa Cruz, ibid., 1946; A. G. DA RochA MADAHIL, "Inventário do Mosteiro de Santa Cruz de Coimbra à data da sua extinção», sep. de O Instituto, ibid., 1943; Joaquim Martins Teixeira de Carvalho, "A Livraria de Santa Cruz de Coimbra», in Boletim Bibliográfico da Biblioteca da Universidade de Coimbra, 1914-1915; ANTÓNIO CRUz, Textos Medievais das «leituras» de Filosofia de Santa Cruz de Coimbra, Porto, 1955; ID., Santa Cruz de Coimbra na Cultura Portuguesa da Idade Média, vol. I, ibid., 1964; ID., Anais, Crónicas e Memórias avulsas de Santa Cruz de Coimbra, ibid., 1968; ID., art, in Verbo. Enciclopédia Luso-Brasileira de Cultura, vol. XVI, 1276-1284; Virgílio Correia e A. NogueIRA Gonçalves, Inventário Artístico de Portugal. Cidade de Coimbra, vol. II, Lisboa, 1947.

(31) Sobre a história da Universidade e o Colégio das Artes, vid. TEófilo Braga, História da Universidade de Coimbra nas suas relações com a Instrução Ptiblica Portuguesa, I-IV, Lisboa, 1892-1902; Mário Brandão, O Colégio das Artes, I-II, Coimbra, 1924-1933; ID., Documentos de D. João III, I-IV, ibid., 1937-1941; Actas dos Conselhos da Universidade de Coimbra de 1537 a 1557, I-III, ibid., 1941-1945; ID., Estudos vários, I-II, ibid., 1974; ID. e M. LOPES DE ALMEIDA, A Universidade de Coimbra. Esboço da sua listória, ibid., 1937; F. CARneiro de Figueiroa, Memorias da Universidade de Coimbra, ibid., 1937; D. Manuel Gonçalves Cerejeira, O Renascimento em Portugal. Clenardo, I-II, ibid., 1917-1918 (reed. em 1926, 1949 e 1975); e algumas das obras citadas para os temas humanismo e erasmismo. 
com o que se passava além fronteiras substitui a leitura das «Sentenças» de Pedro Lombardo pela «Summa» de S. Tomás (1541), segundo uma perspectiva antiescolástica e antidialéctica, no que tiveram um papel fundamental Fr. Bernardo da Cruz e Fr. Martinho de Ledesma, que em Salamanca haviam sido discípulos de Vitória; e emprestou um interesse muito particular aos estudos escrituristicos, dando à cadeira de Exegese Bíblica um carácter estável que antes não tinha, e desdobrando-a em duas (1545) - uma para o Antigo e outra para o Novo Testamento.

\section{EXPRESSÕES DO HUMANISMO PORTUGUÊS}

O humanismo exprimiu-se no início, em Portugal, sob as espécies de um classicismo ainda não em ruptura com os métodos e as travações polémico-doutrinárias de origem medieval. O gosto classicista estava arreigado ainda, de facto, no tempo de D. Manuel, a preocupações e preferências em consonância com os estímulos de uma sociedade em que o escolástico e o eclesiástico tinham ainda um lugar hegemónico. E para esse condicionalismo que apontavam alguns intelectuais da época de D. João III, ao estabelecerem a existência de um contraste cultural, aferido pelos padrões do humanismo, entre o reinado deste monarca e o de seu pai.

No campo das letras, assiste-se, desde Sá de Miranda, a um notável movimento de interesse pelos códices gregos e latinos, pelas línguas eruditas e respectivas literaturas, pelas obras dos humanistas italianos, espanhóis e franceses. São muitos e variados os testemunhos neste sentido, mas não devem esquecer-se os dicionários e gramáticas das línguas sapienciais, os comentários filológicos e as edições críticas dos clássicos, a latinização da língua literária, o uso frequente do latim e do grego em cartas, poesias e outras obras, sobretudo a espantosa erudição de poetas, oradores, moralistas, exegetas, historiógrafos, juristas, nas línguas, literaturas e culturas da Antiguidade, com a sua exploração e reinterpretação pela vanguarda intelectual da Renascença europeia.

Desta explosão cultural, ao mesmo tempo classicista e humanística, resultaram tensões, cujo centro era a polémica entre a luz da Renascənça e as trevas da Idade Média, como se depreende de André de Resende, Arnaldo Fabrício e Hilário Moreira.

O humanismo na literatura doutrinal teve na Ropica Pnefma (1531) de João de Barros, no Desiderii Erasmi encomium (1531) e na Oratio 
pro rostris (1534) de André de Resende e nas obras de Damião de Góis expressão muito significativa (32).

A contextação do medievo e do escolástico, bem como a inflexão «laica» do cristianismo, de evidente inspiração humano-evangelista, caracterizam de forma inequívoca todos aqueles trabalhos.

A obra de João de Barros (33) reflecte a ideologia antinobiliárquica e antieclesiástica do humanismo europeu, designadamente da escola

(32) Sobre o erasmismo em Portugal, vid. além das obras referidas sobre o humanismo: A. EDUARD BEAU, As relações germânicas do humanismo de Damião de Góis, Coimbra, 1941; Eugenio AsEnsio, prólogo da Comedia Eufrosina de Jorge Ferreira de Vasconcelos, Madrid, 1951; ID., «El erasmismo y las corrientes espirituales afines (Conversos, franciscanos, italianizantes)"s, in Revista de Filologia Española, t. XXXVI, Madrid, 1952, pp. 31-99; E. FeIST HrRsch, Damião de Gois - The Life and the thought of a Portuguese humanist, 1502-1574, Haia, 1967; J. V. DE Pina Martins, art. in Dicionário de Literatura, dir. de J. do Prado Coelho, vol. I, Barcelos, 1969, pp. 299-303 (com bibliografia).

(33) João de Barros (ca. 1496-1570), tesoureiro da Casa da Índia, da Casa da Mina e da Casa de Ceuta, um dos grandes clássicos da língua, escreveu, entre outras: Clarimundo (1522), a Ropicapnefma (1532), o Panegirio do Rei D. João III (1533), Diálogo evangélico sobre os artigos da fé contra o Talmud dos Judeus (ca. 1543), as Décadas da Ásia $(1552,1553,1563)$, etc. A Ropicapnefma é no dizer de Marcel Bataillon «o mais original texto de prosa filosófica impresso em Portugal no século XVI» e, segundo I. S. Révah, «a bem dizer desprezado até 1950 pelos historiadores da literatura ou do pensamento português». Seria posta no Index após a sua morte. Acerca do Diálogo evangélico sobre os artigos da fé contra o Talmud dos Judeus, comenta o mesmo Révah: "comovido com a emigração dos cristãos-novos portugueses para a Turquia muçulmana e com o desenvolvimento dos movimentos messiânicos entre aqueles que ficavam em Portugal, o Autor faz um confronto entre os artigos das confissões católica e judaica. Infelizmente, eram medíocres as suas informações sobre o Talmud e da sua obra só podemos colher o sincero desejo duma evangelização pacífica dos cristãos-novos»). A sua publicação foi interdita pela Inquisição. E sobre a sua obra histórica, escreve Révah: «De todos os historiadores da expansão portuguesa no Mundo, João de Barros foi sem dúvida aquele que utilizou fontes mais numerosas e mais autênticas, pois tinha à sua disposição os arquivos, hoje desaparecidos, da Casa da Índia. Entretanto, a sua situação administrativa e a sua concepção da História como "construção retórica e moral» (R. Lapa) impediram-no de escrever a obra de inteira verdade que os modernos esperariam dele. Aliás, conhecia mal os locais e os ambientes da expansão; e também o tolhia uma censura cortesã «imanente» de que se ressentiram todos os historiadores portugueses do séc. XVI. Feitas estas reservas, não regatearemos ao historiador das Décadas o senso da construção da matéria e dos quadros históricos e um estilo particularmente notável nos passos narrativos e descritivos» (Dicionário de Literatura, I, 94-95). - Sobre João de Barros, vid. M. Severim De Faria, Vida 
erasmiana e, até, a de certas correntes mais radicais, como a expressa na Utopia de Tomás Morus. Nas suas páginas não poupa uma certa praxe do cristianismo, de tipo ritualista e formalista, e de cariz clerical, monástico e supersticioso. Ataca a escolástica, o método dialéctico, o cerimonialismo judaico e a concepção materialista de Deus e da religião. Defende que o elemento vital se deve sobrepor ao elemento racional da verdade revelada, a teologia edificante e afectiva ao sistema abstracto do dogma e da moral, a Patrística e a Sagrada Escritura à especulação teológica, e o laicismo cristão ao clericalismo, pois a vida cristã é considerada como uma vida que se vive no mundo, à altura dos leigos, que, tais como os clérigos, têm o direito de abordar os problemas teológicos e religiosos.

André de Resende (34) na Oratio pro rostris aceita sem qualquer reserva os esquemas polémico-culturais de Erasmo e dos seus precur-

de João de Barros, Évora, 1624; António BAIÃo, Documentos inéditos sobre João de Barros, Coimbra, 1917; Estanco Louro, Gramáticos portugueses do séc. XVI, Lisboa, s.d.; A. ForJaz De SAmpaio, História da Literatura Portuguesa Ilustrada, III, Lisboa, 1932; F. Rebelo Gonçalves, «Os filólogos portugueses do séc. XVI», in Boletim de Filologia, IV (1936), pp. 1-13; A. CoRTez PINTo, «A Gramática e a Cartilha de João de Barros», in Liceus de Portugal, Outubro de 1945; H. CidADE, «João de Barros; o que pensa da língua portuguesa; como a escreve», in Boletim de Filologia, XI (1950), pp. 281-303; A. José Saraiva, História da Cultura em Portugal, 2 vols., Lisboa, 1950, 1955; I. S. RÉVAH, «João de Barros», in Revista do Livro, Rio de Janeiro, Março de 1958; ID., ed. do Diálogo evangélico sobre os artigos da fé contra o Talmud dos Judeus, Lisboa, 1950; ID., ed. da Ropicapnefma, 3 vols., de que sairam os dois primeiros dois, ibid., 1952, 1955; ID., «João de Barros», in Dicionário das Literaturas Portuguesa, Galega e Brasileira, Porto, s.d.; R. Morel Pinto, "Gramático portugueses do Renascimento", in Revista de Letras, S. Paulo, 1961; L. STEGNANO, introd. da ed. crítica do Diálogo em Louvor da Nossa Linguagem, Módena, 1959; Luís De MATos, «Acerca dos inéditos de João de Barros», in Actas do III Congresso Internacional de Estudos Luso-Brasileiros, Lisboa, 1959; A. José SARAIVA, «João de João de Barros e a concepção planetária da História», in Para a História da Cultura em Portugal, II, Lisboa, 1962; I. S. RÉVAH, «Antiquité et Christianisme», «Anciens et modernes, dans l'oeuvre de João de Barros», in Revue Philosophique, n. ${ }^{\circ}$ 2, Avril-Juin 1967, pp. 165-185; A. A. Rego Martins, Subsidios para uma edição crítica da «Asia» de João de Barros, Braga, 1963; M. L. Carvalhão Buescu, Textos Pedagógicos e Gramaticais de João de Barros, Lisboa, 1969; ID., João de Barros, Gramática da Lingua Portuguesa, ibid., Lisboa, 1977; ID., Gramáticos portugueses do século XVI, ibid., 1978; A. A. BANHA DE ANDRADE, João de Barros, historiador do pensamento humanista português de Quinhemos, Lisboa, 1980.

(34) Lúcio André de Resende (Évora, 1500-1573) distingui-se como um dos maiores humanistas portugueses. Depois de ter frequentado a Universidade de 
sores italianos. Assim, rejeita não só a concepção escolástica das letras humanas como disciplinas menores e auxiliares, mas os próprios contextos culturais da Idade Média. Advoga a aliança das línguas

Lisboa e professado na Ordem de S. Domingos, cursou as escolas mais importantes da Europa renascentista: em Espanha, as de Alcalá de Henares e de Salamanca, onde teve como mestres Nebrija e Aires Barbosa, e em França a de Paris. Contactou com grandes humanistas do seu tempo, como Erasmo, de todos merecendo a maior estima e admiração. Em Lovaina escreveu, em 1529, o Encomium Lovanii. Foi nesse ano que se encontrou com Clenardo a quem havia de persuadir a, por incubância de D. João III, a aceitar o convite para mentor do rei, o Infante D. Henrique. Esse cargo desempenhou-o ele com vários infantes: D. Afonso, D. Henrique e D. Duarte. Acerca da cultura de Resende escreve Luís da Silva Rebelo: «O seu vasto saber, uma erudição sólida, baseada no conhecimento profundo das letras clássicas, da teologia e história eclesiástica, o seu amor ao estudo e o zelo com que coleccionava achados arqueológicos criaram à sua volta uma atmosfera de fecunda fermentação intelectual, um pequeno cenáculo por academia de reminiscência helénica, cujo influxo no movimento cultural do Renascimento português ainda não foi devidamente apreciado" (Dicionário de Literatura, II, 926). Deixou para cima de cem espécies literárias, nas quais abordou temas e géneros muito variados. Na obra De Antiquitatibus Lusitaniae (1593) despertou entre nós o interesse para os estudos arqueológicos, embora evidentemente esteja condicionada pelos conhecimentos da época. No poema Erasmi Encomium (1531), escrito em hexâmetro dactílico e publicado em Basileia defende abertamente a posição de Erasmo e o livre exame do texto biblico. O mesmo sucede no De Vita aulica (1533). A Oratio pro Rostris (1534) preconiza uma nova reforma mental, aplicada ao sentido e à organização institucional da cultura. Defende, sempre que a ocasião se lhe proporciona, a posição de Erasmo, cuja morte o feriu profundamente. Sobre as outras obras de André de Resende, vid. o artigo citado de Luís da Silva Rebelo e a abundante bibliografia nele referida, da qual destacamos: Carolina M. DE Vasconcelos, «Lucius Andreas Resendius Lusitanus», in Arquivo Histórico Português, vol. III, Lisboa, 1905, pp. 161-178; anselmo Braancamp Freire, Noticias da vida de André de Resende pelo beneficiado Francisco Leitão Ferreira, Lisboa, 1916; Luís DE MATOS, Quatro Orações Latinas de André de Resende, Coimbra, 1937; Gabriel Paiva Domingues, Um discurso de André de Resende (pronunciado no Colégio das Artes, Coimbra, 1555), Coimbra, 1945; A. Moreira de SÁ, introd. à trad. da Oração de Sapiência de André de Resende, pp. XI-XLIII, Lisboa, 1956; Carolina M. DE VASConcelos, «Lucius Andreas Resendius, inventor da palavra Lusíadas», in $O$ Instituto, t. 52, 1905, pp. 241-250; A. Moreira DE SÁ, "O Elogio de Erasmo de André de Resende», in Revista da Faculdade de Letras, Lisboa, III Série, vol. XXIII, n.o 4, 1960, pp. 180-209 (aí se encontra a tradução do mesmo texto por Walter de Sousa Medeiros e J. Pereira da Costa); M. Manuela Barroso de Albuquerque, «André de Resende. O Drama dum Humanista Português»y, in Euphrosyne, nova série, vol. I, Lisboa, 1967, pp. 107-134; J. V. De Pina Martins, Aspectos do erasmismo de André de Resende, Lisboa, 1969. 
eruditas com a ciência teológica, pelo que o ponto de partida para o estudo desta deve ser a filologia e a história. Põe o acento tónico na importância da explanação dos conteúdos da Revelação, salientando o valor da teologia expositiva e edificante em lugar da teologia disputativa e de controvérsia.

No Desiderii Erasmi encomium revela uma enorme admiração pelo roterdamês e uma forte oposição ao integrismo e aos teólogos de Paris e de Lovaina, e aos frades ibéricos que lutavam contra a filosofia cristã de Erasmo. Nele encontramos ideias características do erasmismo: o regresso à Sagrada Escritura, a necessidade de renovação dos processos da exegese bíblica, a rejeição da escolástica e da oposição às belas letras, a denúncia da barbarização da cultura pela inteligência conservadora, a superioridade dos antigos sobre os medievais, a obscuridade cultural da Idade Média e a manutenção do magistério escolástico.

Damião de Góis (35), que também manteve contactos com insignes personalidades ligadas ao irenismo, à reforma e ao progressismo,

(35) Damião de Góis (1502-1574) é «porventura o caso mais proteico e europeizante do Quinhentismo português. Daí - da sua vocação viageira cosmopolita, dos seus contactos, da sua tão vária experiência: «viu e conversou com todos os reis, príncipes, fidalgos e povos da cristandade» - a índole dos trabalhos historiográficos que nos legou com a irritação ambiente e o procedimento inquisitorial a que é submetido no fim da vida», escreve Carlos Eduardo de Soveral. Educado no paço real até 1521 , colocado na feitoria portuguesa de Antuérpia, onde chegou a escrivão e secretário, foi incumbido de várias missões na Holanda e nos países bálticos, e viajou imenso, tendo assim aproveitado o ensejo para contactar com altas figuras do tempo, como Lutero, Melanchton, Luís Vives, Alberto Dürer, que the pintou o retrato, e, sobretudo, com Erasmo, «de quem se tornou amigo tão fiel que uma tradição, não roborada, diz que nos seus braços foi que, abandonado de todos, expirou o autor do Elogio da Loucura». Teve contactos em Itália com os cardeais Bembo e Sadoletto e procurou junto deles, em especial do segundo, que exercessem uma influência particular nos chefes protestantes em ordem a obter-se uma reconciliação com o catolicismo. Depois de várias vicissitudes passadas no estrangeiro, veio a ser nomeado Guarda-Mor da Torre do Tombo (1548). As suas obras mereceram-lhe uma reputação enol'me pela riqueza do seu conteúdo e pelo estilo com que as escreveu. São elas: Ophisculos (impressos em Lovaina, reimpressos em Coimbra, 1791, na Coleção das obras de autores clássicos portugueses que escreveram em latim, que foram traduzidos para português, em 1945, por Dias de Carvalho), De Senectute (versão portuguesa) de Cícero, Livro de Marco Túlio Cícero, chamado Catão maior, ou da Velhice (Veneza, 1534; Lisboa, 1845) e Crónica do Felicíssimo Rei D. Manuel (1566-1567), por incumbência de D. Henrique, Crónica do Príncipe D. João (1567). Evidenciou-se ainda como coleccionador de espécies greco-romanas e musicólogo, 
manifesta reservas quanto ao formalismo cultual e o desejo de uma visão mais evangélica do cristianismo. Mas depois o humanismo modificou-se nele nalguns pontos, devido à preponderância dada ao evangelho da épica portuguesa e ao cruzadismo, e aos condicionalismos sociais em que viveu.

O humanismo, tal como se definiu entre nós no reinado de D. João III, funde numa unidade orgânica três componentes essenciais: o sentido do profano, em termos de valores e de saberes, realçado pelos humanistas de Itália; o anseio evangélico e culturalmente avançado

diplomata e homem de grande convivência social. Acerca do seu trabaiho como historiador, escreve o já citado Carlos Eduardo de Soveral: «Na sua hisoriografia, erudita e ensaística, o escritor sai da vida costumeira no tempo: crítica e judicativa pelos menos tanto como narrativa, a atenção é-lhe antes solicitada por questões de interesse geral e emergente, como a expulsão dos judeus, a matança dos cristãos-novos, a expansão portuguesa, a matéria etíope -, no que se aproxima de Garcia de Resende da Miscelânea -, do que pela aç̧ão do rei, a qual, aliás, Damião de Góis se não furta a considerar severamente, como homem de juízo autónomo que em todo o sentido se não comporta nas fronteiras da convenção portuguesa. Tudo isto, e as referências desfavoráveis que faz a tantos protagonistas do drama, que foi o reinado do Príncipe Perfeito, haveria de ferir interesses e susceptibilizar as gravedades de Espanha, com as quais, através de uma vida «diferente», sempre mantivera atitude polémica, a rariar a heterodoxia». O Santo Ofício moveu-lhe um terrível processo, após o que morıeu em circunstâncias pouco claras. - Sobre Damião de Góis, vid. Gullherme J. C. Henriques, Inéditos Goesianos, 2 vols., Lisboa, 1896, 1898; ID., A Bibliografia Goesiana, ibid., 1911; JoAquim DE VASCONCelos, Goesiana. b) Bibliografia, Porto, 1879; ID., Damião de Góis - Novos Estudos, ibid., 1897; ID., "As Cartas Latinas de Damião de Góis», in O Instituto, vol. 48, 1901; Marcel Bataillon, O cosmopolitismo de Damião de Góis, Lisboa, 1938; Guido Batelli, «Un grande umanista portoghese. Damião di Góis e la sua corrispondenza col Sadoletto e col Bembo", in La Bibliografia, Florença, vol. XLII, 1940; A. E. Beau, As relações germânicas do humanismo de Damião de Góis, Coimbra, 1941; Aubrey Bell, Um humanista português: Damião de Gois, Lisboa, 1942; ElISABeTH FEIST HirsCH, «Damião de Gois's contacts among diplomats», in Bibliothèque d' Humanisme et Renaissance), vol. XXIII, n. ${ }^{\circ} 2$, 1961, pp. 233-251; J. M. TeIXEIRA DE CARvalho e David Lopes editaram a obra de Góis, Crónica do Felicissimo Rei Dom Manuel, 2 vols., Coimbra, 1926; Raul Machado publicou uma tradução de Lisboa de Quinhentos de Damião de Góis em Lisboa, 1937; Isaías da Rosa Pereira, «O processo de Damião de Góis na Inquisição de Lisboa (4 de Abril de 1571 - 16 de Dezembro de 1572), in Anais da Academia Portuguesa da História, 2. ${ }^{a}$ série, vol. 23, t. I, Lisboa, 1975; JEAN Aubin, «Damião de Góis dans une Europe evangélique», in Humanitas, t. XXI-XXXII (1979-1980), 197-227. F. LeITE DE FARIA, Estudos Bibliográficos sobre Damião de Góis e a sua Época, Lisboa, 1977. 
do humanismo cristão; e a consciência das realidades históricas nacionais, sobretudo na dimensão de país descobridor. Para qualquer lado que nos voltemos, para Barros ou para Góis, para Resende ou para Camões, para Sá de Miranda ou Fernão de Oliveira, para os maiores ou para os menores, é com a fusão destes três elementos, com a doutrina e as militâncias emergentes da sua combinação e síntese, que predominantemente nos encontramos. O humanismo português daquela época não é, portanto, um fenómeno de mimetismo, um processo de abastardamento cultural, mas sim um fenómeno e um processo de redefinição da identidade e universalidade do ser e modo de ser lusíadas.

\section{AGONIA E TRANSFORMAÇÃo DO HUMANISMO EM PORTUGAL}

Não constituem um bloco, política e culturalmente uniformes, os anos vinte a sessenta do séc. XVI, em termos de humanismo em Por tugal.

Numa primeira fase, que vai até cerca de 1540, e que podemos designar de porta-aberta, todas as correntes humano-evangelistas tiveram livre curso e acolhimento benévolo no nosso país.

$\mathrm{Na}$ década de 1540 a 1550 , assiste-se a um processo de dúvidas sobre as correntes progressistas, mas estas dominaram, ainda, embora com perda de velocidade de influência.

$\mathrm{Na}$ fase de cinquenta a sessenta as forças integristas conquistam os aparelhos do Estado e preparam-se para ou ensaiam já a eliminação política do progressismo. Esta eliminação foi, porém, obra, sobretudo dos sucessores do Rei Piedoso.

A coluna mestra, o verdadeiro chefe do campo integrista, foi - cardeal-infante D. Henrique. Manifestou-se abertamente pelo classicismo literário associado às aspirações do integrismo católico e ao espírito da Contra-Reforma, motivado, sem dúvida, pela falência dos colóquios de religião e pelas orientações tridentinas. Colocado à frente da inquisição, resistiu com tenacidade às pressões de tolerância feitas por Roma, e a sua actuação orientou-se no plano religioso e cultural de forma a identificar ortodoxia católica com a ideologia de certos estratos de católicos.

Durante a regência de D. Catarina (1557-1562) acentuou-se o progresso do Estado e das instituições para o sistema vital e doutrinal da Contra-Reforma. 
A classe dirigente, que vivia uma grande crise económica, procurava a todo o custo a protecção régia para melhor alcançar o acesso a lugares lucrativos do Paço e da Administração Pública e aos bens das ordens ou corporações religiosas em vias de desamortização.

A fidalguia, criticada com tanta veemência pela sua falta de letras, acomodou-se pouco a pouco à nova situação político-administrativa, registando-se uma enorme percentagem de filhos da classe dirigente a frequentar colégios, conventos, e a Universidade. A cultura surgia como uma necessidade vital para o fidalgo (e também para o clérigo), tendo-se chegado, mesmo, a criar um regime quase de casta em prol das academias universitárias.

Não se torna difícil descobrir as motivações políticas e sociais que determinaram aquele facto. Primeiro, o movimento da história na época da Renascença e da Reforma impunha com força a associação das classes dirigentes com novos e velhos conhecimentos. $\mathrm{O}$ incremento do absolutismo régio e da centralização administrativa, por exemplo, inabilitava, para o exercício de funções no Estado, o aristocrata inculto. As metamorfoses em processo na sociedade marcaram, por outro lado, com o ferrete da inabilidade pastoral, o eclesiástico iletrado.

Depois, porque perante a ameaça da heresia, havia que desenvolver impulsos de resistência a qualquer tipo de infiltrações insidiosas. E um dos caminhos para o objectivo era, claro está, a assimilação do letrado à classe dirigente.

Nessa altura os adversários mais temidos, aqui no continente, eram o judeu e o protestante (a este se associava com frequência o humanista); nos territórios ultramarinos, era o muçulmano.

O judeu era uma ameaça para a suserania da etnia cristã e para a ordem social, dado o seu forte poder sócio-económico; o protestante punha em perigo a posição do corpo eclesiástico na sociedade e a segurança dos interesses económicos da nobreza, embora a sua presença, em Portugal, nunca tivesse sido significativa; o muçulmano, porque havia que salvaguardar os interesses nacionais de além-mar.

Perante estes perigos, sentia-se a urgência de realizar a fusão da cultura e da sociedade no quadro único de um Estado forte e de uma estrutura social hierárquica.

O que se disse atrás acerca das preocupações da nobreza, pode aplicar-se à sociedade eclesiástica, que depressa se consciencializou da ideia de defesa católica. Aliás, através da desamortização de bens e da 
clericatura generalizada, ela tornou-se a solução social para muitos fidalgos e burgueses.

Os dois grandes baluartes do integrismo (36) e da Contra-Reforma, ou seja, as instituições modeladoras foram a inquisição e o ensino.

A primeira, criada em 1536 (e organicamente constituída em 1547), nasceu de uma problemática sociológica e política caracterizadamente peninsular e portuguesa, e não no contexto da luta contra a Reforma ou contra o evangelismo e o humanismo cristão. Falhada a tentativa do integracionismo manuelino, que veio sobrepor-se ao segregacionismo do elemento hebreu na sociedade portuguesa, resolveu-se criar o Santo Ofício, que viria a controlar ideologicamente o país, dirigido em primeiro lugar contra os cristãos novos e de seguida contra qualquer corrente de pensamento suspeita de heterodoxia.

A censura literária, que podemos acompanhar pelos índices de 1547 a 1581, tinha como objectivos o biblismo, o humanismo cristão, atacado de forma indiscriminada juntamente com o luteranismo, a literatura espiritual e de inspiração herética, e visava a exclusão da leitura e da circulação daquelas obras que se consideravam perigosas para a ortodoxia e para a unidade ideológica do país.

As Universidades de Coimbra e de Évora, sobretudo pelas Faculdades de Teologia e de Cânones, garantiam a formação dos espíritos segundo as directrizes da ortodoxia mais rígida em ordem a anularem a sedução das teorias evangélicas ou suspeitas de perigosas.

(36) Sobre a censura e a inquisição em Portugal, vid., entre outros: AleXandre Herculano, História da origem e do estabelecimento da inquisição em Portugal, 3 vols., reed. Lisboa, 1975-76; A. BAIÃo, Episódios dramáticos da inquisição portuguesa, 3 vols., reed. 1972-73; J. Lúcio DE AzEVEDo, História dos cristăos novos portugueses, reed., Lisboa, 1975; Fortunato de Almeida, História da lgreja em Portugal, vol. III, 2. ${ }^{a} \mathrm{p}^{\mathrm{e}}$; vol. IV, 3. ${ }^{a} \mathrm{p}^{\mathrm{e}}$, reed., 1971; A. José SARAIVA, A inquisição portuguesa, Lisboa, 1956; Isaías DA Rosa Pereira, «Notas sobre a inquisição em Portugal no séc. XvI», in Lusitania Sacra, t. 8, Lisboa, 1978; HenRy KamEN, Histoire de l'Inquisition espagnole, trad., Paris, 1965; A. Martins de Carvalho, art. "Santo Ofício», in Dicionário de História de Portugal, dir. de Joel Serrão, vol. III, pp. 774-779; B. LlorCa e J. MatToso, art. "Inquisição», in Verbo. Enciclopédia Luso-Brasileira de Cultura, vol. X, cols., 1510-1522; I. S. RÉvaH, La censure inquisitoriale portugaise ali XVI siècle, Lisboa, 1960; G. Almeida Rodrigues, Breve história da censura literária em Portugal, Lisboa, 1980 (com abundante bibliografia); J. Perez Villanueva (dir.), La inquisición española, Nueva Visión, nuevos horizontes, Madrid, 1980. 
Ainda quanto à Faculdade de Teologia, convém não esquecer que nela se fez sentir a viragem ideológica que se estava a processar: o método dialéctico-polémico tradicional sobrepôs-se ao método positivo-expositivo da época do humanismo, e os estudos bíblicos decairam significativamente.

A Companhia de Jesus tornara-se instrumento importante de vigilância religiosa e dominava em todos os centros do ensino preparatório, no Colégio das Artes, por exemplo, que em 1555 passou para as suas mãos, depois de terem sido processados pela inquisição vários dos seus mestres. As «postilas» de que sairam os Commentarii Collegii Conimbricensis constituem passos importantes para se chegar a um padrão ideológico que norteasse duradouramente o pensamento nacional.

O pluralismo ideológico cristão, posto em causa ao nível da imprensa pela censura inquisitorial, sofreu assim uma «capitis diminutio» gravíssima à escala pedagógica. O humanismo fabro-erasmiano, o irenismo e o evangelismo católico viram-se excluídos do direito à existência no âmbito escolar.

Fez-se, nesta época, um vasto esforço para cortar os contactos dos portugueses com a problemática e os veículos literários do humanismo cristão. Através da escola e da censura literária, como já dissemos; mas através também dos meios de intimidação social e de repressão individual.

Era o signo do Concílio de Trento que para isso impelia; não ، ra, contudo, menos o signo da preservação de interesses de classe postos em causa onde o luteranismo obtinha êxito político.

Estes factores não explicam, entretanto, por si sós, a agonia do humanismo cristão em Portugal e a sua transformação (de que falaremos no capítulo seguinte) em humanismo católico. É preciso ter ainda em consideração (aliás factor de peso bastante importante) o empenhamento do país na expansão ultramarina. Não só esta repulsava certas teses do humanismo cristão - o anticruzadismo, por exemplo, mas apelava para uma unidade ideológica pouco compatível com o minimalismo dogmático, o pluralismo teológico, o tolerantismo religioso, o culto desformalizado, que aquela corrente humanista segregava. A fundamentação teoideológica da expansão e os princípios da actividade missionária são inseparáveis do ser português e do pensar em português do séc. XVI.

Seria erróneo supor-se que a agonia do humanismo : ristão no nosso país foi uma expressão de conformismo com a cultura que tínha- 
mos e com a Igreja que tínhamos antes do reinado de D. João III. Fez-se, pelo contrário, um vasto esforço para renovar, espiritual e moralmente, por um lado, a vida e a cultura do clero, e por outro as formas da prática religiosa dos fiéis.

A actividade, neste campo, vem já do séc. XV, sob o impulso do movimento da restauração católica, com eco nos concílios de Constança e Basileia, e intensificou-se, pelo que respeita às ordens mendicantes, no reinado de D. Manuel. Mas foi, sem dúvida, na época de D. João III que atingiu o «climax».

Nas ordens militares, de Cister e de S. Agostinho, de S. Bento e da $S^{a}$ Trindade, em Santa Cruz de Coimbra e nos conventos franciscanos e dominicanos, para só referir algumas congregações, realizou-se nesta altura, apesar das reacções surgidas, um gigantesco trabalho de renovação e restauração da vida religiosa que há muito se aguardava.

Nalguns casos podemos caracterizar até o espírito que animou os reformistas. Assim, em Santa Cruz de Coimbra, as semelhanças com o pensamento de Windesheim são flagrantes. Fr. Brás de Barros, ao dar as suas preferências à cultura escriturística e patrística em prejuízo da cultura escolástica, ao misticismo rusbroquiano e ao ideal evangélico-humanístico de Lefèvre e de Erasmo, situava-se na linha do genuíno reformismo católico tão em voga nessa época, além fronteiras.

Caracterizações análogas se poderiam fazer, se o tempo o permitisse, quanto à reforma da ordem de $\mathrm{S}$. Francisco e da ordem de S. Domingos. Não poderá esquecer-se, em todo o caso, o papel destas congregações na articulação de uma austeridade rigorosa da vida com uma interiorização significativa do culto.

Uma palavra especial é, contudo, devida ao que se passou na esfera do clero diocesano. Iniciativas importantes tinham já sido tomadas, quer sob o signo do concílio de Basileia, quer sob o signo do V concílio de Latrão. É, todavia, com o impulso do concílio de Trento que vai fazer-se um grande esforço de purificação e «aggiornamento» do clero diocesano, análogo ao que estava em curso no âmbito dos institutos regulares.

No que toca à escolha de prelados, verifica-se que, ao lado dos bispos palacianos, começaram a aparecer os pastores de almas, como Baltasar Limpo e Bartolomeu dos Mártires, em Braga; Julião de Alva, em Portalegre e em Bragança; Gonçalo Pinheiro, em Viseu; Brás de Barros e Gaspar do Casal, em Leiria; Rodrigo Pinheiro, no Porto, etc. 
Embora este vigoroso impulso de renovação se tivesse verificado em todas as dioceses e ordens religiosas, o certo é que já a partir do segundo quartel do séc. XVI em muitas delas se vinha processando uma profunda reforma moral e espiritual preconizada e desejada com tanto ardor por pessoas de sensibilidade religiosa mais fina, como Luís de Granada e André de Resende.

Mas devem recordar-se também Fr. Valentim da Luz e Fr. Bartolomeu dos Mártires que lutaram imenso em prol das reformas eclesiásticas. O último, seguindo o pensamento da ala avançada do catolicismo e na linha de Paulo de León, Bartolomeu Carranza, Luís de Granada, Jerónimo Seripando e Carlos Borromeu, realizou uma extraordinária obra de renovação da vida religiosa, sendo de salientar a insistência que punha na doutrina austera e na oração mental, e na valorização da espiritualidade e do ministério pastoral.

Dada a audácia com que Mártires defendeu certas ideias, houve quem o quisesse aproximar de Erasmo, o que é um erro. Embora à semelhança deste, aspire a uma profunda reforma e a uma autêntica revitalização da prática religiosa segundo o espírito, o certo é que as diferenças de pontos de vista em vários aspectos da teologia e da espiritualidade são enormes. Basta dizer, em síntese, que Erasmo é um humanista cristão, ao passo que o arcebispo de Braga é um humanista católico.

No que respeita ao pietismo português e ao iluminismo, deve sublinhar-se que ambos receberam forte influência dos autores estrangeiros, de modo particular espanhóis e italianos, que nalgumas das suas correntes derivavam dos místicos do Norte e noutras dependiam das ideias erasmianas. Mas importa chamar a atenção para o facto de que os porta-vozes do pietismo e do iluminismo portugueses estavam comprometidos a sério nos problemas e inquietações próprio de um meio, cujas estruturas sociais tinham evoluído muitíssimo desde o alvor dos descobrimentos e em que as incidências estrangeiras se tinham reflectido com moderação.

O humano-evangelismo, como alternativa político-religioso-cultural, perdeu toda a viabilidade desde que a fractura da unidade da Igreja se tornou um facto consumado por cerca de 1550 , e depois que o concílio de Trento procedeu ao reajustamento dogmático e disciplinar do catolicismo e da sua ideologia e estratégia global.

A reforma católica, como o humanismo cristão, desde esse momento, perderam todo o poder de intervenção, quer à esc.la da 
doutrina quer à escala da militância. Chegava a. hora da Contra-Reforma e do humanismo católico.

\section{O HUMANISMO CATÓliCO}

A vitória da Contra-Reforma teve, em Portugal (37), consequências fatais para o destino do humanismo cristão e do próprio humanismo religiosamente descomprometido. Estes sobreviveram apenas nas suas

(37) Tratando da Contra-Reforma, Jean Delumeau na sua obra Naissance et affirmation de la Réforme (4. ${ }^{a}$ ed., 1973, p. 159 ss.) alude ao clima de intolerância, à reconquista pelas armas e à tomada das massas. Os primeiros mártires da Reforma morreram em Antuérpia em 1523 e depois até ao séc. XVIII vamos encontrar muitas vitimas da hostilidade que colocou lado a lado católicos e protestantes. As guerras de religião foram um acontecimento a todos os títulos lamentável no contexto das relações entre as duas confissões religiosas. Mas, como escreve Delumeau não se pode reduzir a Contra-Reforma a este aspecto. E aponta os casos de Francisco Xavier, de Vicente de Paulo, das batalhas de Lepanto (1571) e de Viena (1683), das correntes místicas que floresceram em Espanha por fins do séc. XVI, da elevada espiritualidade beruliana, da aç̧ão dos jesuítas no Paraguai, do extraordinário florescimento da teologia positiva - exegese bíblica, patrística, história dos dogmas, história eclesiástica - e da arte barroca. Ora, em todos estes casos referidos não existe nada que se possa classificar de luta anti-protestante. Até no concernente à arte barroca, «une des grandes expressions de l'âme religieuse», no dizer de V.-L. TAPIÉ em Baroque et classicisme (Paris, 1957). Mas não há dúvida que a luta pelas armas foi um facto. Territórios que tinham passado para o lado protestante eram agora reconquistados muitas vezes e então tentava-se converter as populações através de missões, da criação de colégios e universidades, etc. Escreve J. Delumeau: «Par définition même, le terme de "Contre-Réforme" signifie la volonté murement délibérée de faire disparaître le Protestantisme, au besoin par la force. Or cette volonté, on ne la trouve pas toujours au cours des guerres de Religion. Charles Quint cherchait assurément à rétablir l'unité religieuse de l'Empire, mais il aurait volontiers accepté d'importantes conceccions à la Réforme, si Rome n'y avait pas fait obstactle». E aponta outros exemplos. Mas Roma aprovava naturalmente as aç̧ões militares levadas a cabo pelos prínticpes católicos contra os protestantes (vid. J. Delumeau, Vie économique et sociale de Rome dans la seconde moitié du XVI ${ }^{\mathrm{c}}$ siècle, Paris, $1957-$ -1959, II, p. 761). Fernando II, rei da Boémia a partir de 1617 e imperador em 1619 é uma das figuras caracteristicas da Contra-Reforma. Fez sua a divisa de S. Inácio de Loiola: ad majorem Dei gloriam. Dizia: «Senhor, se a tua glória e a minha salvação querem que eu me torne poderoso, eleva-me e eu te glorificarei; se exigem que eu continue onde me encontro, apoia-me e eu te glorificarei; se pedem que eu seja chassé, humilha-me e eu te glorificarei» (Lamorain, Ferdinandi virtutes, Viena, 1638, p. 31, citado por J. Delumeau, Naissance el affirmation de la Réforme, op. cit., p. 165).

O mesmo autor alude ainda ao que o legado do papa, Carlo Carafa, escreveu acerca da batalha do Monte Branco, felicitando-o efusivamente. Nos países reconquista- 
dimensões ciceronianas de humanismo formal, isto é, de produto sintético da combinação do classicismo literário e da problemática ideológico-tridentinista.

dos pelas autoridades católicas, seguia-se o programa de Inácio de Loiola, traçado em 1554 numa carta dirigida a Pedro Canísio: «...O rei não deveria tolerar no seu conselho nenhum herege e nem dar a impressão de ter em alta estima uma espécie de homens cujos intentos, públicos ou secretos, não têm em definitivo outro fim que não seja favorecer e desenvolver a impiedade herética de que são imbuídos». E diz mais que nenhum herege deve ser investido de autoridade, sobretudo suprema, nem ter cargos públicos sejam eles quais forem ou dignidade. As honras e riquezas devem ser-lhes retiradas. E aconselha mesmo a expulsar os professores e alunos suspeitos de heresia, a queimar os livros dos hereges «mesmo se o seu conteúdo não é herético», como a Gramática, a Retórica ou a Dialéctica de Melanchton. E sugeria que se fizessem promulgar os decretos dos concílios, que se escolhessem bons bispos, que viessem à Alemanha pregadores em grande número, que não se conferissem paróquias senão a pessoas instruídas, que se ensinasse o caiecismo à juventude, que se criassem colégios e seminários... O fundador da Companhia de Jesus situava-se na linha apregoada pela Igreja de Roma. Em 1542, Paulo III criara a congregação da Inquisição o que tinha provocado a fuga para fora de Itália de um grupo de humanistas heterodoxos. Ochino, Pedro Mártir Vermigli, Celio Secundo Curione, Mino Celsi, Camillo Renato, Flacius Illyricus, etc. Em 1564, Pio IV, seguindo as recomendações das sessões XVIII e XXV do concílio de Trento, publicou o primeiro Index de livros próbidos. Depois de dizer que o concílio de Trento foi um momento extraordinário do mundo católico, citando de seguida L. WiLlaERT, La restauration catholique (1563-1648), vol. XVIII da Histoire de l'Église de Fliche-Martin, Tournai, 1960, p. 24, escreve J. Delumeau: «Mais il a été aussi un refus de dialoguer avec la Réforme, une affirmation abrupte de positions antiprotestantes». A Bíblia e a língua vulgar na Missa, não foram concedidas aos leigos. Estes viram-se afastados da participação activa nos actos litúrgicos. Estes aspectos viriam a ser alterados no concílio Vaticano II. Mas não há dúvida que foi enorme o conjunto de realizações levadas a efeito (vid. L. WiLlaERT, op. cit., p. 88 ss.; p. 180 ss. etc.) como a criação de seminários e de universidades, em que os jesuítas ocuparam um lugar importante. L. WILlaERT compara a Europa do séc. XVII com a do séc. V: «L'Empire de Rome se limitait alors au Rhin et au Danube. Or si l'on pointe sur la carte do XVII ${ }^{e}$ siècle les universités qui forment au nord le boulevard de l'Eglise de Rome, on note sur le Rhin inférieur - ou tout proche: Louvain et Douai, Münster, Osnabrück, Paderborn, Cologne et Trèves; dans la région rhénane moyenne ou supérieure: Pont-à-Mousson, Mayence, Wurzbourg, Bamberg, Heidelberg et Molsheim; Fribourg-en-Brisgau, Lucerne, Fribourg-en-Suisse; sur la ligne du Danube, Dillingen, Ingolstadt, Salzbourg, Gratz et Vienne. De cette ligne à peine incurvée, partira la reconquête romaine d'une partie de l'Allemagne. En face, la ligne oposée des universités protestantes: Leyde, Erfurt, Wittenberg, Bâle et Genève, Marbourg-en-Hesse, Helmstadt, Tubingen, Rostock, Iéna, Francfort-sur-Oder, Kònigeberg... Si le Catholicisme a pu se maintenir en Allemagne et racheter en partie ses pertes, c'est principalement grâce à ces citadelles de la science théologique». 
Morreu então, na cultura portuguesa, a doutrina, em larga medida também a prática, que reclamava a guerra à escolástica e à cultura medieva. Morreram de igual modo as esperanças que apontavam para o fim do formalismo cultual, para a desclericalização da sociedade cristã, a desromanização da Igreja, a liquidação do monaquismo, a liberdade de pensamento no âmbito cristão, a autonomia dos autores profanos em face do magistério teológico e até a sua concepção como sucedâneo deste. Foi a vez de um humanismo que pedia ao classicismo os modelos literários e as referências exemplares, mas que recebia das dominâncias da Contra-Reforma a problemática, a dialéctica, a tensão polémica, o sentido do discurso.

O humanismo formal, entronizado no ensino pela Companhia de Jesus, não se manifestou, porém, entre nós com uma acentuação unívoca. A acentuação é uma nos filósofos e teólogos, que o tomaram sobretudo pelo lado das técnicas e dos conteúdos científicos. É outra em boa parte nos poetas novi-latinos, que o receberam pelas suas possibilidades literárias e riqueza de erudição. É outro ainda nos poetas e prosadores que, através do maneirismo ou da literatura ideologicamente comprometida, se integraram na ambiência do contra-reformismo.

A teoria literária do humanismo formal vinha a esboçar-se desde a obra de Jorge Coelho e de André de Resende na sua última fase. Deu passos importantes com os poetas vulgares e novi-latinos da segunda metade do séc. XVI, e consumou-se com Jerónimo Osório, Cosme de Magalhães e Cipriano Soares (38).

O humanismo, assim entendido, era considerado nos colégios jesuíticos não só como a base do acesso à filosofia e à teologia, mas também como disciplina do espírito e cultura do homem ilustrado. É assim que nos aparece na De Societatis Jesu Gymnasiis oratio de Pedro Perpinhão ( ${ }^{39}$ ), proferida no Colégio das Artes em 1555. O mesmo

(38) Pedro João Perpinhão escreveu Orationes duodeviginti, Roma, 1587; Manuel Álvares é o autor de De institutione grammatica libri tres, Lisboa, 1572; Cipriano Soares de De Arte Rhetorica libri tres ex Aristotele, Cicerone, et Quintiliano praecipue diprompti, Coimbra, 1562. - Sobre Jerónimo Osório, autor de notáveis obras, algumas delas de carácter bíblico, temos no prelo um estudo sobre «A obra exegética de D. Jerónimo Osório» a publicar em Theologica. Vid. art. de A. Costa RamalHo, in Verbo. Enciclopédia Luso-Brasileira de Cultura, vol. 14, 873-874 (com bibliografia).

(39) Heitor Pinto escreveu In Isaiam Commentaria, Lião, 1561; In Ezechielen Prophetam Commentaria, Salamanca, 1568; In Divinum vatem Danielem Commen- 
fizeram Manuel Álvares e Cipriano Soares nos manuais de gramática e de retórica que escreveram para uso dos discípulos. O humanismo é por eles apreciado não como uma cultura - a profana e das coisas

taria, Coimbra, 1579; In Prophetae Ieremiae Lamentationes, Coimbra, 1579; In divinum Nahum Commentarii, 1579; estas obras tiveram várias edições e foram depois incluídas nos Opera Omnia. Dele se conservam alguns trabalhos biblicos manuscritos e Barbosa Machado refere outros que se perderam. A sua Imagem da Vida Cristã (Coimbra, 1563, etc.), já pelo seu conteúdo e intenção, já por ter sido escrita em português e num estilo atraente, foi a obra de Heitor Pinto que mais aceitação e maior divulgação teve, quer entre nós, quer no estrangeiro, através de traduções. E tem sido também a obra mais estudada pelos críticos literários. - Sobre os Diálogos de Amador Arrais (1 ${ }^{a}$ ed., Coimbra, 1563), escreve Jacinto do Prado Coelho: «A obra é valioso documento da mentalidade da época, moldada pelo espírito da Contra-Reforma; traduz o orgulho imperial, associado a uma visão providencialista da História, o entranhado anti-semitismo, o gosto humanístico de citar moralistas e poetas da Antiguidade. Parte dos dez diálogos tem cunho ascético e devoto: «Da consolação para a hora da morte», p. ex. Elegante e sóbrio, Arrais é notável prosador; ele próprio diz ter posto «concerto nas palavras» a fim de também agradar aos «letrados». O último diálogo encerra belas páginas sobre Nossa Senhora; o A. deixou-se contagiar pelo que chama as «delícias e flores dos insignes poetas cristãos» (Dicionário de Literatura, vol. I, Porto, 1969, 68, com bibliografia). De Heitor Pinto e Luís de Sotomaior tratamos longamente no nosso livro A Cátedra de Sagrado Escritura na Universidade de Coimbra. - Primeiro Século (1537-1640), Coimbra, 1974; e Fr. Heitor Pinto Exegeta, ibid., 1972; Recentemente publicámos nas Actas do Simpósio Internacional sobre João de Ruão (Coimbra, 1980) um estudo sobre «Fr. Heitor Pinto no contexto da cultura da Renacença».

Jerónimo de Azambuja (Oleastro) escreveu Commentaria in Moisi Pentateuchum (Antuérpia, 1569; Lião, 1586) que reúne os comentários aos diversos livros do Pentateuco publicados individualmente; In Isaiam Prophetam Commentarii (Paris, 1622) e Hebraismi et Canones pro intellectu Sacrae Scripturae (Lião, 1566-1588) e ainda outros trabalhos exegéticos que hoje se não conhecem. Sobre Azambuja escrevemos: "Algum aspectos da obra exegética de Fr. Jerónimo de Azambuja (Oleastro), O.P.», in Revista Portuguesa de História, XVII (1977), 25-36; «A obra exegética de Fr. Jerónimo de Azambuja, O.P. - Os cânones bíblicos e o prefácio ao Pentateuco», in Biblos, LV (1979), 183-195, e recentemente um artigo no Dicionário de História da Igreja em Portugal, vol. II, 60-62.

Francisco Foreiro escreveu Iesaiae Prophetae Vetus et Nova ex Hebraico Versio cum Commentario (Veneza, 1563, etc.). Sobre este autor, vid. J. Nunes Carreira, Filologia e Crítica de Isaías no Comentário de Francisco Foreiro (1522?-1581), Braga, 1969; ID., e o nosso estudo A Cátedra de Sagrada Escritura na Universidade de Coimbra. Primeiro Século (1537-1640), Coimbra, 1974, onde tratamos de outros exegetas portugueses; e temos em preparação um trabalho sobre a «História da Exegese Bíblica em Portugal» a sair na Revista da Universidade de Coimbra.

Luís de Sotomaior compôs Cantici Canticorum Interpretatio (Lisboa, 1599-1601), Ad Canticum Canticorum Notae Posteriores et Breviores (Paris, 1611) 
profanas -, mas como uma forma ou instrumento ao serviço da doutrina católica recentemente aprovada em Trento.

É nesta ordem de ideias que podemos falar da renovação das ciências eclesiásticas e da vida religiosa. Não só em Portugal, mas também

e Commentarius in Priorem et Posteriorem Pauli Apostoli Epistolam ad Timotheum et item in Epistolam eiusdem Apostoli ad Titum (Paris, 1610).

Diogo de Paiva de Andrade é o autor de Orthodoxarum explicationum libri $X$ (Colónia, 1564), Defensio Tridentinae Fidei Catholicae (Lisboa, 1578); Sermoens (3 vols., Lisboa, 1603, 1605 e 1615). A polémica entre Andrade e Chemnitius foi célebre. O seu tratado Examen Concilii Tridentini e outros que deixou traduzem bem o clima que então se vivia na perspectiva da Reforma e da Contra-Reforma. Sobre Paiva de Andrade escrevemos: "Algumas Notas sobre a Vida e a Obra de Diogo de Paiva de Andrade», in Revista Portuguesa de História, vol. XV (1974), pp. 321-327; "Diogo de Paiva de Andrade - IV Centenário da sua Morte», in Revista de História das Ideias, vol. I (1976), pp. 237-286; «A oração proferida por Diogo de Paiva de Andrade no Concílio de Trento», in Theologica, II Série, vol. XII-fascs. I-IV (1977), 193-21l; e art. in Dicionário de História da Igreja em Portugal, vol. I, 224-225. A grande estima e amizade que uma Paiva de Andrade a Jerónimo Osório estão bem patente no texto que a seguir se transcreve:

Illustrissimi et Reverendissimi D. Hieronymi Osorii Episcopi Silvensis et Algarbiorum, Epistola ad universam Christianam Rempublicam

Quanta iactura facta sit in morte Dieghi (sic) Payvae, illi iudicare possunt, qui mores illius, qui virtutem, qui praeclaras artes illius nobilitates dignas, qui religionis studium quo mirifice tenebatur, qui omnem denique illius cursum exploratum et cognitum habuerunt. Ex quibus ego si principem locum inter illius amicos vindicavero, iure me facere statuent omnes, quibus nostra coniunctio poenitus nota fuerit. Illum namque adolescentem indole praeclara praeditum cognovi: iuvenem egregie dilexi: aetate iam maturiore ardentius amavi; et ita meum in illum amorem in dies vehementius excitari sentiebam. Cum enim nihil sit virtute amabilius, consequens est, ut pro virtutis progressione amoris similiter progressio fiat. Cum igitur ille semper aliquid ad cumulum virtutis addidisset, necesse erat bonorum amorem erga illum indies amplificari. Erat in illo summum ingenium, ardens studium, singularis industria, quibus muneribus naturae praestantis, et virtutis eximiae locupletatus cum se ad artes praeclaras inflammato animo contulisset, uberrimos fructus consecutus est. Eloquentiae vero disciplinam egregie coluit: linguas quas vidit esse ad clariorem sacrarum litterarum intelligentiam necessarias acri studio didicit; hisque opibus instructus ad divina mysteria perscrutandam totam mentem applicuit. Has autem opes animi minime compressas domi continebat; sed eas omnes ad ecclesiae fructus et utilitatem contento studio conferebat. Ex Paulo enim didicerat finem legis esse caritatem. Ergo cum ranitatis studium illius animo acres stimulos admoveret, contineri non poterat, quin crebris concionibus multos mortales flagitiis innumerabilibus inquinatos instrueret; et in viam immortalitatis aberrima contentione revocaret. Quantam vero laudem in Conciclio Tridentino fuerit adeptus quis 
noutros países, assistiu-se neste período a um extraordinário surto das disciplinas teológicas - da teologia especulativa à apologética, da pastoral à ascética e à mística, dos estudos bíblicos ao direito canónico e à eloquência sagrada - para o que muito contribuiram o impulso

ignorat? Vidi non ita pridem in Italia apud Ecclesiae principes impressa illius vestigia ad diuturnam eruditionis et eloquentiae monumentum. Multi namque viri et doctrina, et pietate, et dignitate praestantes Payvam in coelum laudibus efferebant. Sed de laudibus illius ne plura dicam illarum numerus est impedimento. Si enim omnes pro dignitate persequi vellem dies me fortasse deficeret. Possem merito vicem meam lamentari, quod morte illius amico sim privatus mecum singulari amicitiae fide, et multorum officiorum magnitudine coniunctum. Sed iniuriam faciam Payvae, si eum in mortuis numeravero. Non moriuntur enim iusti, sed vita sempiterna cum gloria immortali perfruuntur. Spirat praeterea illius virtus atque religio in illius monumentis quibus pro ecclesiae sanctitate fortissime dimicavit; et impiorum hominum perditos conatus magna belli contentione compressit. Cum autem in Concilio Tridentino librum edidisset singulari eruditione cumulatum, quo sanctam hominum religiosorum sodalitatem qui de Iesu societate nominantur, contra convicia hominis impurissimi defendebat; et alia multa in eo libro valde ad fructum religionis utilia sapienter adiuinxisset, virum amentem exagitavit, usqueo dum graviores in ecclesiam contumelias intorquecet. Fuit igitur opus ut Payva more suo rursus arma sumeret; et hostem immanem insita virtute profligaret. Cum veros omnes haereticorum conatus eo comparentur, ut auctoritatem ecclesiae furentur affligant, Pontificis Maximi dignitatem de solio detrudant, conciliorum decreta rescindant (sic enim fore vident, ut moderatione funditus eversa omnium bonorum perturbatio consequatur, et furor immanis in universa Republica dominetur) praeclarissime a Payva factum est, cum causam ecclesiae suscepit, ut hominum perditorum amentiam refutaret, et hostilem impetum fortiter et animose reprimeret. Librum igitur et sapienter et eleganter scriptum, quo homines profligatos et perditos acerrime convincebat, in Galliam Belgicam misit ut pulcherrimis Plantini typis impressus ad universae ecclesiae utilitatem perveniret. Fuit navis in qua liber ferebatur a piratis capta, et liber in hominum male de religione sentientium potestatem perductus, quod vir optimus admodum aegre tulit. Verebatur enim ne liber sub illius nomine inquinatus haereticorum erroribus in lucem prodiret. Ut igitur hoc periculum vitaret, operam summo studio dabat ut typis Olysippone mandaretur, cum morte impeditus fuit, quo minus conata perficeret. Huic tanto incommodo a fratribus amantissimis egregie subventum fuit. Id enim egerunt, ut opus pure et diligenter impressum in lucem prodiret. Hortor igitur et moneo omnes, qui ecclesiae sanctitatem venerantur, ut hos libros diligenter evolvant. Quod si fecerint multa reperient a nostro Payva sapienter admodum disputata, et non parum eleganter illustrata, ita ut non solum doctrina illius iuvari, verum et orationis luminibus oblectari facile possint»» (Defensio Tridentinae Fidei Catholicae et integerrimae quinque libris compraehensa, adversus Haereticorum detestabiles calumnias et praesertim Kemnicii Germani, Lisboa, 1578, prefácio). 
dado pelo concílio de Trento, a necessidade de defender a fé atacada pelos protestantes e até as discussðes surgidas entre os sábios católicos.

Nota-se que muitos dos nossos autores, filósofos, teólogos e exegetas, manifestam um domínio perfeito das línguas eruditas e dos conhecimentos filológicos e possuem uma bagagem de conceitos morais e culturais fornecidos pelos escritores gregos e latinos. E servem-se muitas vezes das técnicas humanísticas e da autoridade dos clássicos, como sucedeu com Heitor Pinto, Amador Arrais, Jerónimo de Azambuja, Francisco Foreiro, Luís de Sotomaior, Diogo de Paiva de Andrade, os Conimbricenses, etc.

Também se assistiu a uma profunda renovação da vida religiosa, que se reflectiu na instituição de seminários, na reforma litúrgica, na criação de novas ordens religiosas e na renovação das antigas, na elevação da vida moral, etc.

O colapso do humanismo laico e do humanismo cristão situa-se dentro deste panorama. A partir do segundo quartel do séc. XVI, humanismo e cristianismo passaram a ser considerados como coisas contraditórias.

Com efeito, nem a Faculdade de Teologia nem a Companhia de Jesus pensavam como André de Resende e outros, anos atrás, segundo os quais devia existir uma aliança indissolúvel entre o humanismo e o cristianismo.

O triunfo pleno da tese contra-reformista e a ideia de defesa católica levaram a colocar as letras humanas ao serviço do Estado e da Fé. O humanismo laico e o humanismo cristão eram tidos como uma contaminação herética insidiosa da cultura e da prática católicas.

As opções humano-evangelistas muitas vezes assimiladas às teses luteranas eram condenadas aber amente. O humanismo ia sendo cada vez mais reduzido a um humanismo formal oficializado na escola e na cultura portuguesas.

Manuel Augusto Rodrigues 


\title{
INSTITUTO DE HISTÓRIA E TEORIA DAS IDEIAS
}

\author{
$\mathrm{E}$
}

CENTRO DE HISTORIA DA SOCIEDADE

E DA CULTURA DA UNIVERSIDADE DE COIMBRA

\section{PUBLICAÇÕES:}

J. S. Da Silva Dias, Braga e a cultura portuguesa do Renascimento, Coimbra, 1972

Lứs MANUEL ReIS TORGaL, Tradicionalismo e contra-revolução-o pensamento e a acção de José da Gama e Castro, Coimbra, 1973

J. S. DA SIlva Dias, Os Descobrimentos e a problemática cultural do século XVI, Coimbra, 1973

José Eduardo Horta Correia, Liberalismo e catolicismo - o problema congreganista (1820-1823), Coimbra, 1974

J. S. Da Silva Dias, Regimento escolar de Santa Cruz de Coimbra (1537), Coimbra, 1974

José Esteves Pereira, Silvestre Pinheiro Ferreira - o seu pensamento politico, Coimbra, 1974

J. S. DA Silva Dias, O erasmismo e a Inquisição em Portugal -o processo de Frei Valentim da Luz, Coimbra, 1975

Maria Manuela Tavares Ribeiro, Conflitos ideológicos do século XIX - o problema pautal, Coimbra, 1976

Luís MAnUel Reis ToRgal, A Restauração - reflexões sobre a sua historiografia, Coimbra, 1976

Jaime Raposo Costa, A teoria da liberdade - periodo de 1820 a 1823, Coimbra, 1976

Zllita MARIA Osório DE CASTRo, Manuel Borges Carneiro e a teoria do estado liberal, Coimbra, 1976

José Esteves Pereira, Henriques Nogueira e a conjuntura portuguesa, 1846-1851, Coimbra, 1976

António J. da Silva Pereira, $O$ «tradicionalismo» vintista $e$ o Astro da Lusitânia, Coimbra, 1976

Manuel Augusto Rodrigues, Diogo de Paiva de Andrade - IV centenário da sua morte, Coimbra, 1976

Maria Fernanda Reis Figueira, A Faculdade de Teologia perante o materialismo (1861-1905), Coimbra, 1976

João Francisco de Almeida Policarpo, O pensamento social do grupo católico de «A Palavra» (1872-1913), vol. I, Coimbra, 1977

Maria Helena da Cruz Coelho, O Mosteiro de Arouca do século $X$ ao século XIII Coimbra, 1977 
Fernando de Almeida Catroga, Os inicios do positivismo em Portugal - o seu significado politico-social, Coimbra, 1977

Graça Silva Dias, António Aleixo - problemas de uma cultura popular, Coimbra, 1977

JoÃo Francisco de Almetda Policarpo, $O$ «bom operário»-estudo de uma mentalidade, Coimbra, 1979

António J. Da Silva Pereira, Estado de direito e «tradicionalismo» liberal, Coimbra, 1979

Maria Beatriz Nizza da Silva, A repercussão da revolução de 1820 no Brasileventos e ideologias, Coimbra, 1979

Albert Silbert, Les invasions françaises et les origines du libéralisme au Portugal Coimbra, 1979

ZiLIA MARIa OSÓRIO DE CASTRo, A sociedade e a soberania-doutrina de um vintista, Coimbra, 1979

Maria Manuela Tavares Ribeiro, Teorias e teses literárias de António Pedro Lopes de Mendonça, Coimbra, 1980

Graça Silva Dias, De Gil Vicente a Camões - culturase mentalidades, Coimbra, 1980

Graça e J. S. Da Silva Dias, Os primórdios da maçonaria em Portugal, ts. I a IV, Coimbra, 1980

AmÂndio A. Coxito, $O$ compêndio de lógica de $M$. de Azevedo Fortes e as suas fontes doutrinais, Coimbra, 1981

Amadeu Carvalho Homem, Do «lluminismo» ao Positivismo-Joaquim António da Silva Cordeiro e a sua obra, Coimbra, 1981

José MARIA ANDré, Os descobrimentos portugueses e a teoria da ciência no século XVI, Coimbra, 1981

Manuel Augusto Rodrigues, Do humanismo à contra-Reforma em Portugal 